\title{
Membrane vesicles, current state-of-the-art: emerging role of extracellular vesicles
}

\author{
Bence György • Tamás G. Szabó • Mária Pásztói · Zsuzsanna Pál • \\ Petra Misják • Borbála Aradi • Valéria László • Éva Pállinger • \\ Erna Pap · Ágnes Kittel · György Nagy • András Falus · Edit I. Buzás
}

Received: 6 January 2011 / Revised: 30 March 2011 / Accepted: 12 April 2011 / Published online: 11 May 2011

(C) The Author(s) 2011. This article is published with open access at Springerlink.com

\begin{abstract}
Release of membrane vesicles, a process conserved in both prokaryotes and eukaryotes, represents an evolutionary link, and suggests essential functions of a dynamic extracellular vesicular compartment (including exosomes, microparticles or microvesicles and apoptotic bodies). Compelling evidence supports the significance of this compartment in a broad range of physiological and pathological processes. However, classification of membrane vesicles, protocols of their isolation and detection, molecular details of vesicular release, clearance and biological functions are still under intense investigation. Here, we give a comprehensive overview of extracellular vesicles. After discussing the technical pitfalls and potential artifacts of the rapidly emerging field, we compare results from meta-analyses of published proteomic studies on membrane vesicles. We also summarize clinical
\end{abstract}

B. György and T. G. Szabó contributed equally.

B. György · T. G. Szabó · M. Pásztói · Z. Pál · P. Misják ·

B. Aradi · V. László · É. Pállinger · E. Pap · G. Nagy ·

A. Falus · E. I. Buzás (ه)

Department of Genetics, Cell- and Immunobiology,

Semmelweis University, Budapest, Nagyvárad tér 4,

Budapest 1089, Hungary

e-mail: edit.buzas@gmail.com

M. Pásztói · É. Pállinger · A. Falus

Research Group for Inflammation Biology and

Immunogenomics, Hungarian Academy of Sciences,

Nagyvárad tér 4, Budapest, Hungary

Á. Kittel

Institute of Experimental Medicine, Hungarian Academy

of Sciences, Szigony utca 43, Budapest, Hungary

G. Nagy

Department of Rheumatology, Semmelweis University,

Frankel Leó utca 54, Budapest, Hungary implications of membrane vesicles. Lessons from this compartment challenge current paradigms concerning the mechanisms of intercellular communication and immune regulation. Furthermore, its clinical implementation may open new perspectives in translational medicine both in diagnostics and therapy.

Keywords Exosome - Microvesicle $\cdot$ Microparticle . Apoptotic body - Cancer · Platelet - Biomarker . Autoimmune disease

$\begin{array}{ll}\text { Abbreviations } & \\ \text { ADAM17 } & \begin{array}{l}\text { ADAM metallopeptidase } \\ \text { domain } 17\end{array} \\ \text { AFM } & \text { Atomic force microscopy } \\ \text { ARF6-G } & \text { ADP-ribosylation factor 6 } \\ \text { ATP } & \text { Adenosine triphosphate } \\ \text { CBS } & \text { Center of Biological Sequence } \\ & \text { Analysis } \\ \text { CEA } & \text { Carcinoembryonic antigen } \\ \text { CLL } & \text { Chronic lymphocytic leukemia } \\ \text { DLS } & \text { Dynamic light scattering analysis } \\ \text { DVT } & \text { Deep vein thrombosis } \\ \text { EGFRvIII } & \text { Epidermal growth factor receptor } \\ & \text { variant III } \\ \text { eMV } & \text { Endothelial cell derived } \\ \text { ERK } & \text { microvesicle } \\ \text { EV } & \text { Extracellular signal-regulated } \\ \text { FC } & \text { kinase } \\ \text { GPIIb/IIIa } & \text { Extracellular vesicle } \\ \text { HER-2 (or Her2/Neu) } & \text { Fuman epidermal growth factor } \\ & \text { receptor 2 } \\ & \end{array}$




$\begin{array}{ll}\text { HIV } & \text { Human immunodeficiency virus } \\ \text { ITP } & \begin{array}{l}\text { Idophathic thrombocytopenic } \\ \text { purpura } \\ \text { Lysosome-associated membrane } \\ \text { protein 1 }\end{array} \\ \text { LIMK } & \text { LIM domain kinase } \\ \text { LMV } & \begin{array}{l}\text { Leukocyte cell derived } \\ \text { microvesicle }\end{array} \\ \text { LPS } & \text { Lipopolysaccharide } \\ \text { MelanA/Mart-1 } & \text { Melanocyte antigen A/Melanoma } \\ \text { miRNA } & \text { antigen recognized by T cells 1 } \\ \text { MLCK } & \text { Micro RNA } \\ \text { MV } & \text { Myosin light-chain kinase } \\ \text { MP } & \text { Microvesicle } \\ \text { NYHA } & \text { Microparticle } \\ \text { P2X(7)R } & \text { New York Heart Association } \\ \text { pMV } & \text { Functional Classification } \\ \text { RA } & \text { P2X purinoceptor 7 } \\ \text { RhoB } & \text { Platelet-derived microvesicle } \\ & \text { Rheumatoid arthritis } \\ \text { ROCK kinase } & \text { Ras homolog gene family, } \\ \text { SLE } & \text { member B } \\ \text { TAM } & \text { Rho-associated protein kinase } \\ \text { SEM } & \text { Systemic lupus erythematosus } \\ \text { TYRO3, AXL and MER receptor } & \text { protein kinases } \\ \text { Transmission electron } & \text { micropscopy } \\ \text { TIM4 } & \text { T cell immunoglobulin and mucin } \\ \text { domain containing 4 } & \text { Tumor suppressor activated } \\ \text { pathway-6 } & \text { Tumor susceptibility gene 101 } \\ \text { TSAP6 } & \end{array}$

TSG101

\section{Introduction}

The extracellular space of multicellular organisms contains solutions of metabolites, ions, proteins and polysaccharides. However, it is clear that this extracellular environment also contains a large number of mobile membrane-limited vesicles for which we suggest the term "extracellular vesicles" (EVs). EVs include exosomes, activation- or apoptosis-induced microvesicles (MVs)/microparticles and apoptotic bodies (Fig. 1). In conventional histological sections, recognition of the secreted membrane vesicles is substantially limited by the resolving power of the light microscope, as their diameter usually falls below the limit of resolution. Furthermore, not only histological assessment but also conventional cell biology techniques including laser confocal microscopy or flow cytometry (FC) have substantial limitations when used for analysis of
Extracellular vesicles

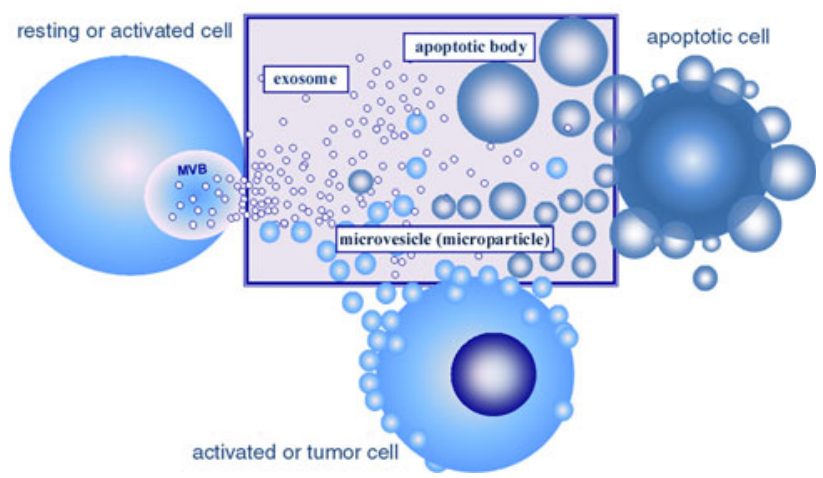

Fig. 1 Schematic representation of the extracellular vesicles. Major populations include exosomes, microvesicles and apoptotic bodies. To simplify the Figure, cells are not shown to release all types of vesicles

EVs [1]. Thus, it was not until recently that emerging evidence started to support the notion that vesicle release may be a universal adaptive cellular response (Fig. 2) [2-4].

Although initially met with skepticism, the existence of secreted membrane vesicles is now well established, and their diverse biological functions have been documented extensively. Current research interest in the field focuses primarily on two major types of EVs (exosomes and MVs), whose release may represent a universal and evolutionarily conserved process. Of note, EVs also include other vesicular structures such as large apoptotic bodies as well as exosomelike vesicles and membrane particles [2]. Exosome-like vesicles have common origin with exosomes; however, they lack lipid raft microdomains, and their size and sedimentation properties distinguish them from exosomes [2, 5]. Membrane particles are $50-80 \mathrm{~nm}$ in diameter, and they originate from the plasma membrane [6]. Extracellular membraneous structures also include linear or folded membrane fragments (e.g., from necrotic death) as well as membranous structures from other cellular sources including secreted lysosomes [7] and nanotubes [8].

In fact, in the extracellular environment of tissues, different types of vesicles are present simultaneously. Therefore, instead of focusing on a single type of vesicle, in this review article we summarize data on membrane vesicles collectively, from a systems biology perspective. Without claiming completeness, we discuss recent developments and some burning questions in the field.

As a step towards standardization of the terminology, we use the terms suggested recently by Théry et al. [2]. The only exception is that we use the collective term "extracellular vesicle" (EV) as a synonym of "membrane vesicle" (the designation that has been suggested for all populations of cell-derived vesicles). The phrase "exosome" refers to vesicles of $50-100 \mathrm{~nm}$ in diameter, 


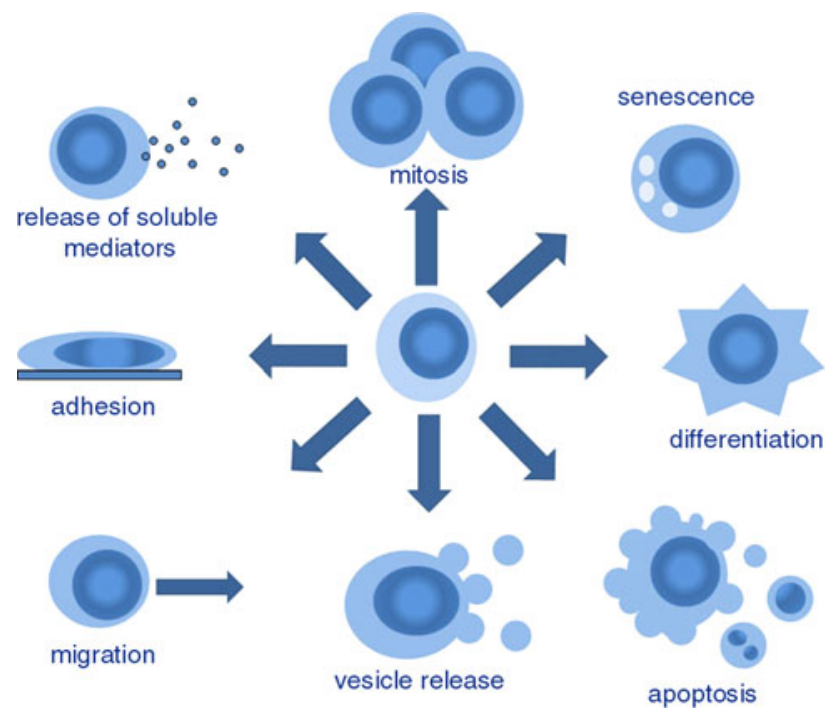

Fig. 2 Summary of some adaptive cellular responses including the newly recognized vesiculation process. Of note, apoptosis itself involves vesicle release (shedding of apoptotic microvesicles and apoptotic bodies)

generated by exocytosis of multivesicular bodies (MVBs). Of note, biological literature also uses the term "exosome" for a macromolecular complex involved in RNA degradation, while the word "ectosome" (used by some authors to indicate neutrophil or monocyte derived MVs [9]), also refers to the outer, cortical layer of sponges [10]. "Microparticle" is a general designation used for any small particles within a given size range irrespective of origin. Even in biomedical literature the term "microparticle" is commonly used in the case of biopolymer particles (used as drug delivery systems), or dietary microparticles (food additives, pharmaceutical or toothpaste microparticles) [11], to mention just a few examples of the redundant terminology. Given that the word "particle" suggests a solid, particulate structure rather than a vesicular one, the designation "microvesicle" appears more appropriate to indicate membrane-limited structures. However, over the past decades, most studies traditionally referred to these structures as "microparticles" [e.g. endothelial cell- and platelet derived MVs were designated as endothelial microparticles (EMPs) and platelet microparticles (PMPs), respectively]. Of note, the term "microvesicle" has also been used by several authors collectively for vesicular structures released by cells instead of "membrane vesicles".

To make the terminology unambiguous in this review, we will use the term "microvesicle" for the larger extracellular membrane vesicles $(100-1,000 \mathrm{~nm}$ in diameter), and we will not use the term "microparticle" [2]. The abbreviation "MV" denotes "microvesicle" and not "membrane vesicle".

\section{Release of membrane vesicles: trogocytosis}

From a cell biology perspective, vesiculation may be classified as a type of trogocytosis. The transfer of membrane components between donor and acceptor cells was first demonstrated in 1973 [12]. The phenomenon has been coined "trogocytosis" (from Greek "trogo", meaning "gnaw" or "bite"). Some authors suggest that trogocytosis challenges classical theories of cell autonomy [13], as cells may receive membrane and cytoplasmic fragments from other cells. Two forms of membrane transfer (trogocytosis) have been described: via nanotubes or via membrane vesicles [8]. This review focuses on membrane vesicles of the extracellular environment.

The biogenesis of membrane vesicles essentially distinguishes exosomes from MVs and apoptotic bodies.

In the following section, we provide a concise overview of hallmarks of paramount membrane vesicle populations: exosomes, MVs and apoptotic bodies.

\section{Key features of major vesicle populations}

Key features of exosomes

- Exosomes were first described by Trams et al. [14] as exfoliated vesicles with ectoenzyme activity. This work was followed by the results of Harding and Stahl describing release of small vesicles and tubules from rat reticulocytes [15], and an electron microscopic study describing the exocytosis of the approximately $50-\mathrm{nm}$ bodies [16]

- They are vesicles surrounded by a phospholipid bilayer (approximately $50-100 \mathrm{~nm}$ in diameter), their size range roughly overlaps that of the viruses (Fig. 3)

- They are released both constitutively and upon induction [2] by exocytosis of multivesicular bodies (MVBs), important intermediates in endolysosomal transport formed by the invagination and scission of buds from the endosomal limiting membrane into the lumen [17]

- Exosomes have been predominantly characterized in the case of immune cells (dendritic cells, T cell, B cells, macrophages) and tumors

- Key mechanisms by which exosomes may exert their biological functions on cells include (1) direct contact between surface molecules of vesicles and cells, (2) endocytosis of vesicles, and (3) vesicle-cell membrane fusion [2]. Exosomes may horizontally transfer mRNA and miRNA [18]. Horizontal transfer of oncogenic receptor [19] and transfer of HIV particles [20] have been demonstrated in the case of exosomes. 
Fig. 3 Size ranges of major types of membrane vesicles. While exosomes share size distribution with viruses, microvesicles overlap in size with bacteria and protein aggregates (e.g. immune complexes). Both apoptotic bodies and platelets fall into the size range of $1-5 \mu \mathrm{m}$

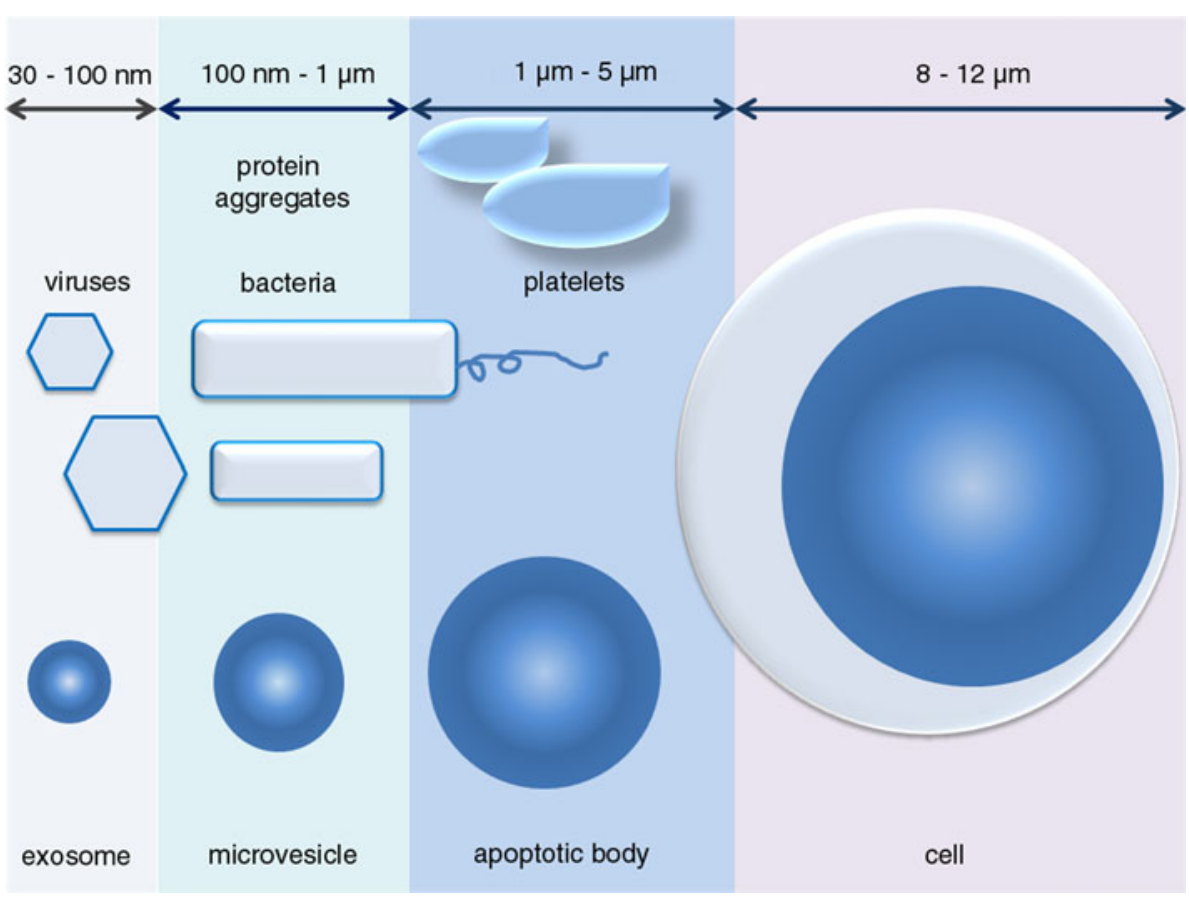

- Examples for key functions of exosomes include antigen presentation $[2,21]$ and immunostimulatory and inhibitory activities [2].

- They feature phosphatidylserine on the outer membrane leaflet [22], and markers include CD63, CD81, CD9, LAMP1 and TSG101 [23, 24]

- Isolation and analytical methods include differential centrifugation and subsequent sucrose gradient ultracentrifugation [25], transmission electron microscopy (TEM), western blot and mass spectroscopy
- Basic features of exosomes have been recently covered by numerous review articles [2, 22, 23, 26-35] (Table 1)

Key features of microvesicles (MVs)

- MVs were first described by Chargaff and West in 1946 as a precipitable factor in platelet free plasma with the potential to generate thrombin [36]. In 1967, Peter Wolf

Table 1 Key features of membrane vesicle populations

\begin{tabular}{|c|c|c|c|}
\hline & Exosomes & Microvesicles & Apoptotic bodies \\
\hline Size range & Approximately $50-100 \mathrm{~nm}$ & $\begin{array}{l}100-1,000 \mathrm{~nm}(\sim 100-400 \mathrm{~nm} \text { in } \\
\text { blood plasma) }[2,22,38]\end{array}$ & $1-5 \mu \mathrm{m}[61]$ \\
\hline Mechanism of generation & By exocytosis of MVBs & $\begin{array}{l}\text { By budding/blebbing of the plasma } \\
\text { membrane }\end{array}$ & $\begin{array}{l}\text { By release from blebs of cells } \\
\text { undergoing apoptosis }\end{array}$ \\
\hline Isolation & $\begin{array}{l}\text { Differential centrifugation and sucrose } \\
\text { gradient ultracentrifugation [25], } \\
100,000-200,000 \mathrm{~g}, \text { vesicle } \\
\text { density is } 1.13-1.19 \mathrm{~g} / \mathrm{mL}\end{array}$ & $\begin{array}{l}\text { Differential centrifugation [39] } \\
\quad 18,000-20,000 g\end{array}$ & $\begin{array}{l}\text { Established protocols are } \\
\text { essentially lacking; most } \\
\text { studies use co-culture with } \\
\text { apoptotic cells instead } \\
\text { of isolating apoptotic bodies }\end{array}$ \\
\hline Detection & $\begin{array}{l}\text { TEM, western blotting, mass } \\
\text { spectrometry, flow } \\
\text { cytometry (bead coupled) }\end{array}$ & $\begin{array}{l}\text { Flow cytometry, capture based } \\
\text { assays }[38,52]\end{array}$ & Flow cytometry \\
\hline $\begin{array}{l}\text { Best characterized cellular } \\
\text { sources }\end{array}$ & Immune cells and tumors & $\begin{array}{l}\text { Platelets, red blood cells and } \\
\text { endothelial cells }\end{array}$ & Cell lines \\
\hline Markers & $\begin{array}{l}\text { Annexin V binding, CD63, CD81, CD9, } \\
\text { LAMP1 and TSG101 }[23,24]\end{array}$ & $\begin{array}{l}\text { Annexin } \mathrm{V} \text { binding, tissue factor } \\
\text { and cell-specific markers }\end{array}$ & Annexin V binding, DNA content \\
\hline Recent review articles & {$[2,22,23,26-35]$} & {$[2,24,35,53-57]$} & \\
\hline
\end{tabular}


described "platelet dust", a fraction containing mainly lipid-rich particles separated by ultracentrifugation from fresh plasma [37]

- MVs are structures surrounded by a phospholipid bilayer. They are $100-1,000 \mathrm{~nm}$ in diameter [2] or $\sim 100-400 \mathrm{~nm}$ in blood plasma [38], but the lower cutoff remains to be established [39]. Their size range overlaps that of bacteria and insoluble immune complexes [38] (Fig. 3)

- They are formed by regulated release by budding/ blebbing of the plasma membrane.

- The rate of steady state release of budding/shedding vesicles [35] is generally low (except for tumors that release them constitutively [40]).

- Regulated release of vesicles is efficiently induced upon activation of cell surface receptors or apoptosis and the subsequent increase of intracellular $\mathrm{Ca}^{2+}[41,42]$

- They have been predominantly characterized as products of platelets, red blood cells and endothelial cells.

- Examples of key functions of MVs: they have procoagulant activity [43], represent a form of secretion of IL $1 \beta$ [44], contribution to the pathogenesis of rheumatoid arthritis [45-47], contribution to the proinvasive character of tumors [48], induction of oncogenic cellular transformation [49], fetomaternal communication [50]

- They feature phosphatidylserine; however, some observations also suggest the existence of MVs without phosphatidylserine externalization [51]

- Routine isolation and analytical methods include differential centrifugation [39], flow cytometry (FC) and capture-based assays [38, 52]

- Basic characteristics, molecular and functional aspects have been summarized by several recent review articles [2, 24, 35, 53-57]

Key features of apoptotic bodies

- The term "apoptotic body" was coined by Kerr in 1972 [58], and the next milestone work in apoptosis research was conducted by Robert Horvitz et al. tracing cell lineage development in the nematode Caenorhabditis elegans [59, 60]

- Apoptotic bodies are 1-5 $\mu \mathrm{m}$ in diameter (approximately the size range of platelets) [61]

- Apoptotic bodies are released as blebs of cells undergoing apoptosis

- They are characterized by phosphatidylserine externalization, and may contain fragmented DNA [62]

- Examples of key functions of apoptotic bodies are horizontal transfer of oncogenes [63], horizontal transfer of DNA [64], yielding presentation of T cell epitopes upon uptake by phagocytic cells [65] and representation of B cell autoantigens [66]. Uptake of apoptotic bodies has been shown to lead to immunosuppression [67].

- Instead of isolating apoptotic bodies, most studies use co-cultures of cells undergoing apoptosis to investigate the functions of these structures.

In spite of extensive research, the rapidly emerging field of membrane vesicle research remains technically difficult. In the next section, we aim to overview major challenges and recent methodological improvements.

Problems and pitfalls associated with membrane vesicle measurement

In this section, we aim to summarize the difficulties associated with isolation of membrane vesicles and standardization of pre-analytical and analytical factors of membrane vesicle assessments.

\section{Isolation of membrane vesicles}

There is a widely accepted protocol for exosome isolation, which includes ultracentrifugation and a subsequent sucrose density gradient ultracentrifugation or, alternatively, sucrose cushion centrifugation [25]. In contrast, standard isolation protocols for MVs are lacking. Most groups apply centrifugation conditions from $18,000 \mathrm{~g}$ (30 min) to $100,000 \mathrm{~g}$ (60 $\mathrm{min}$ ) [68]. Standard isolation protocols for apoptotic bodies are absent in the literature. In biological fluids and cell supernatants, the previously described membrane vesicle populations are present simultaneously with possible size overlap. While immune affinity isolated exosomes have been shown to have a diameter $<100 \mathrm{~nm}$ [69], it has not yet been convincingly demonstrated that all MVs are larger than the 100-nm limit. Moreover, the statement that MVs may not be $<100 \mathrm{~nm}$ should be made with some caution. Booth et al. have shown vesicles of this size (and even smaller) budding from the plasma membrane [70].

A further substantial problem is that during differential centrifugation prior to pelleting of a given membrane vesicle population, some of the respective vesicles may be selectively depleted. For example, centrifugation of cells or platelets results in a substantial loss of MVs [71]. To analyze bloodderived MVs, platelet-free plasma is required. However, currently there is no consensus on the centrifugation times, forces or the number of cycles for the removal of platelets. For complete removal of platelets, an 800-nm filtration is required after centrifugation [38]. Of note, forced filtration of membrane vesicles holds the risk of fragmentation into smaller vesicles [72]. To avoid this problem, we recommend gravitydriven filtration [38]. 
In conclusion, the isolation of membrane vesicles by differential centrifugation is complicated by the possibly overlapping size distributions of platelets and different membrane vesicle populations. Furthermore, centrifugation alone may prove insufficient to separate vesicles based on their sizes. However, differential centrifugation, when combined with sucrose gradient ultracentrifugation, can separate exosomes from MVs. A further alternative method to differential centrifugation, immunoisolation of membrane vesicles, may overcome these limitations [25, 69].

\section{Size determination of different membrane vesicle populations}

Despite the existence of several methods available to determine the size of vesicles, the precise determination of the size distribution of a given vesicle preparation seems to be unexpectedly difficult. FC is a convenient technique; however, it has severe limitations in resolving structures below $200 \mathrm{~nm}$ [22]. The gold standard for vesicle size determination remains transmission electron microscopy (TEM) [1]. For TEM studies, vesicles need to be concentrated by centrifugation. However, there are some concerns about the reliability of analysis of pelleted vesicles: centrifugation, dehydration and fixaton for TEM may alter the size and morphology of vesicles. Newer techniques (such as cryo-EM) led to the finding that the "cup-shaped" morphology of exosomes was an artifact related to fixation for TEM [25]. Despite these concerns, TEM is the only method by which the nature of the particle, its size and structure may be determined at the same time. Surfacebound particles are studied by atomic force microscopy (AFM). AFM has some limitations in analyzing non-rigid particles: the $z$ value (the height of the particle) seems to be much smaller than the $x, y$ values (characteristic for the surface area) [73]. Yuana et al. hypothesized that the vesicle volume is constant; therefore, the diameter of surfacebound vesicles is much smaller than the $x, y$ values, if we consider the low $z$ value. However, the low $z$ value may also result from the tapping mode analysis of the AFM (the up- and downward motion of the AFM tip may cause deformation of vesicles) or from the drying step. This is supported by our AFM data showing concordant results with TEM and dynamic light scattering analysis without a correction for the $z$ value [38].

Dynamic light scattering analysis (DLS) is a useful method for membrane vesicle sizing; however, it has limitations, particularly when the analyzed system is polydisperse. Our work based on TEM, AFM and DLS analysis, supported by the work of others [72], suggested that the blood plasma-derived $\mathrm{MVs}$, isolated by $20,500 \mathrm{~g}$ centrifugation, were $100-400 \mathrm{~nm}$ in diameter $($ mean $=170 \mathrm{~nm})[38]$. Nanoparticle tracking analysis is an alternative method to DLS and, particularly in the fluorescent mode, it is capable of analyzing highly polydisperse structures between 50 and 1,000 nm [1]. Results obtained with this method are highly concordant with the TEM measurements [1]. Other methods for vesicle size determination such as stimulated emission depletion microscopy or fluorescence correlation spectroscopy have been recently reviewed by van der Pol et al. [1].

\section{Pre-analytical challenges}

There are growing concerns about pre-analytical variables, particularly in the field of the diagnostic use of MVs. These pre-analytical factors were addressed insufficiently by earlier works in the literature. However, there are data regarding the alterations of the MV count in erythrocyte concentrates and platelet-rich plasma. It has been shown that platelets vesiculate in response to shear stress [74] and storage [75] (Fig. 4). In the study of Connor et al., it has been shown that freeze-thaw cycles of platelet-rich plasma resulted in a substantial increase of annexin $\mathrm{V}^{+} \mathrm{MV}$ count [51]. In erythrocyte concentrates, the MV count varies with storage time, temperature, the buffer used to dilute MVs, and, most interestingly, with agitation [71]. Rubin et al. have shown that vortexing the erythrocyte concentrates for $20 \mathrm{~s}$ doubled the MV count [71]. These data strongly suggest that cells, particularly platelets and erythrocytes, are highly sensitive to environmental factors and respond by release of MVs (Fig. 4), which may lead to confounding results. As a consequence, during the assessment of

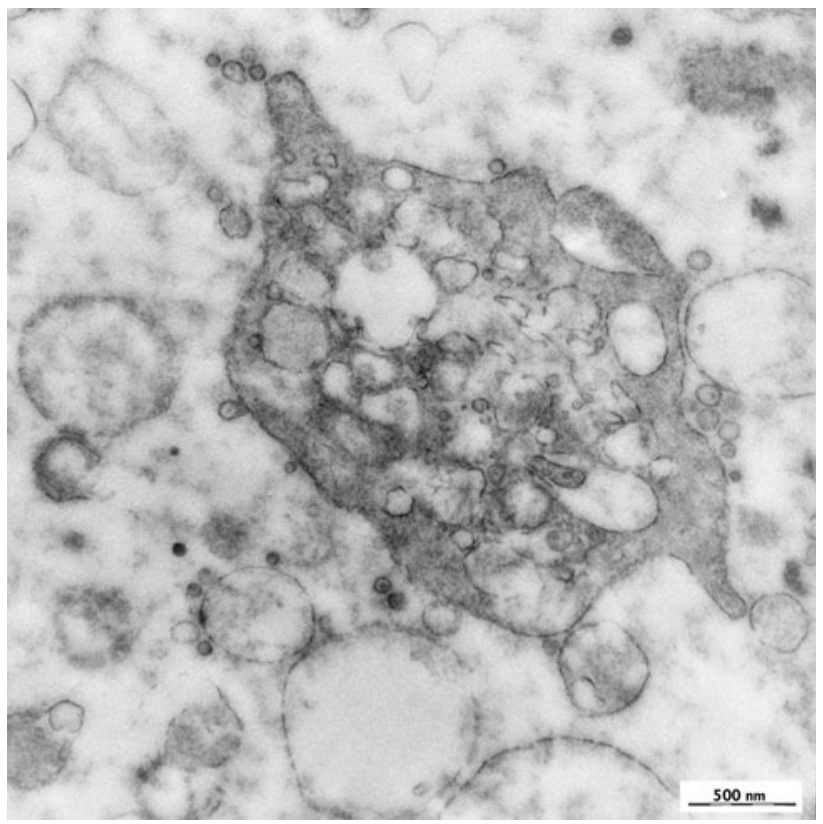

Fig. 4 Transmission electron micrograph of a platelet from normal human blood plasma releasing membrane vesicles (pMVs). Original magnification $\times 30,000$ 
MVs in routine diagnostic approaches, all steps from venipuncture to sample analysis must be standardized precisely. These steps include (1) the diameter of the needle used for venipuncture, (2) duration of placement of the tourniquet, (3) the type of anticoagulants used, (4) centrifugal speed to yield platelet-free plasma, (5) working and storage temperature of the sample, (6) freeze-thaw cycles, (7) needle-to-analysis time, and (8) analysis protocols $[39,76]$. It is critical that cells and platelets from biological fluids be pelleted shortly after collection (preferably within an hour), and before frozen stage. In order to minimize the effect of pre-analytical variables, recently, a workgroup has launched a joint project on standardization of MV analysis (International Society on Thrombosis and Haemostasis, Scientific and Standardization Committee: Standardization of Pre-analytical Variables in Plasma Microparticle Determination). The preferred protocol includes collection of blood samples in citrate containing tubes. In order to deplete blood samples in platelets, centrifugation twice with $2,500 \mathrm{~g}$ for $15 \mathrm{~min}$ is recommended (F. Dignat-George, personal communication). After snapfreezing in liquid nitrogen, the samples should be stored at $-80^{\circ} \mathrm{C}$

On the other hand, there are only limited data on preanalytical variables in the case of exosomes. Some preanalytical challenges have been demonstrated with respect to urinary exosomes as new biomarkers of kidney disease. During the pre-centrifugation step, urinary exosomes may become entrapped in the polymeric Tamm-Horsfall protein leading to a loss of exosomes [77]. Furthermore, possible viral contamination with the common presence of several hosts molecules, e.g., MHC-II molecules in both virions and exosomes, also need to be considered during exosome detection. Optiprep velocity gradients have been recently suggested to efficiently separate exosomes from HIV-1 particles [78].

\section{Flow cytometric detection of membrane vesicles}

As described above, standard FC detects vesicles above approximately $\sim 200 \mathrm{~nm}$, and therefore exosomes and smaller MVs cannot be analyzed directly by this method. Thus, it has to be emphasized that MVs smaller than the detection limit of the used flow cytometer cannot be discriminated from the instrument noise, leading to an inadequate numbering of MVs (because of not detecting the vast majority of vesicles that are present in the sample). Despite these limitations, FC is a widely used method for MV detection, and using FC, many studies have reported that MV counts correlated with a variety of diseases and different physiological conditions. Recently, there have been major improvements in the standardization of FC measurements of membrane vesicles $[79,80]$. This is a prerequisite for the diagnostic and prognostic use of MV measurements. FC platforms for small size EV analysis are being developed by BD, Beckmann Coulter, Apogee; however, these are not yet widely available (except for the Apogee system).

In many of the earlier FC studies, annexin $\mathrm{V}$ was used as a common marker for MVs. However, recent studies suggest the presence of annexin V-negative MVs. Indeed, it has been reported that annexin $\mathrm{V}$-negative MVs account for more than $80 \%$ of the platelet-derived vesicles in blood plasma [51]. This study controlled for the effect of annexin $\mathrm{V}$ binding, demonstrating that it requires at least $1.25 \mathrm{mM}$ calcium for binding. They also drew attention to the fact that phosphate-buffered saline was not suitable for annexin $\mathrm{V}$ staining, as calcium forms precipitates with phosphate. In line with these results, in our work, we have found that saline with $2.5 \mathrm{mM} \mathrm{Ca}^{2+}$ results in an optimal annexin $\mathrm{V}$ staining [38]. Given that not all vesicles are annexin V positive, alternative labelings of MVs with PKH67 [81] or bio-maleimide [82] may also prove useful to examine correlations between MV counts and human disorders. In blood, the most important sources of MVs are platelets, and most studies analyzed the alterations of levels of plateletderived microparticles (pMVs) under several conditions and diseases. Recent studies have suggested that the majority of the CD41 ${ }^{+}$pMVs were derived from megakaryocytes rather than from platelets [83]. The megakaryocyte-derived vesicles did not carry CD62P, but displayed full-length filamin A [83]. Further studies are required to clarify the potential diagnostic and/or prognostic values of megakaryocyte-derived vesicles.

An additional problem is that any structure that shares size and consequently scattering properties with MVs, would also appear during FC within the gate used for MP detection. We have demonstrated recently that insoluble immune complexes may also give signals at FC, and thus interfere with MV measurements. When all events are considered as MVs within the MV gate, the presence of immune complexes in RA synovial fluid may overestimate true vesicle counts [38]. Furthermore, we showed that, when using indirect labeling, primary and secondary antibodies formed immune complexes detectable within the MV gate as fluorescent events. Importantly, not only immune complexes but alo streptavidine-biotinylated antibodies and antibody aggregates may form supramolecular protein complexes detectable within the MV gate. The MV and protein complex-related events may be easily discriminated by using low concentrations of detergents enough to lyse MVs but insufficient to disassemble immune complexes and protein aggregates [38]. The optimal concentration of the detergent (i.e., Triton X-100), which discriminates vesicles from protein aggregates, should be titrated for individual settings. Furthermore, it is recommended to use only direct immunolabelling when 
staining vesicles in order to avoid immune complex formation. However, it is important to note that some vesicle subpopulations may be particularly resistant to such lysis; therefore, detergent lysis may not be considered as a guarantee to lyse all types of membrane vesicles.

To conclude, FC is a powerful technique to analyze membrane vesicles; however, as it has serious limitations, all FC data on membrane vesicles should be interpreted cautiously.

\section{Potential contamination of membrane vesicle preparations}

To study the effect of secreted membrane vesicles, it is of high importance to examine isolated vesicle populations. Beyond membrane vesicles, biological fluids may also contain high amounts of different types of particles (lipoproteins, viruses) or molecules with the tendency to form aggregates or complexes. These complexes or particles not only disturb the detection of membrane vesicles (as discussed in the previous section), but may also co-sediment with various membrane vesicle populations. Roughly, exosomes overlap in size with viruses and lipoproteins, while MVs overlap the size range of bacteria (Fig. 3). In the case of viruses, even sucrose gradients are inefficient at separating them from exosomes [78]. This problem may be solved using iodixanol gradients, which have been shown to separate exosomes from retroviruses [78]. Furthermore, proteins may also contaminate isolated exosome preparations, as suggested by Rood et al. [84]. The authors showed that, after ultracentrifugation or nanomembrane ultrafiltration, the pellet contained very high amounts of contaminating proteins from patients with nephrotic syndrome. Our group has also shown that preparations of MVs isolated by differential centrifugation may be contaminated by protein complexes, especially by insoluble immune complexes [38]. We have demonstrated shared size and sedimentation properties of immune complexes and MVs, which may result in contamination of conventionally isolated MV preparations.

Membrane vesicle populations may also be contaminated by microsomal fractions or organelles released from necrotic cells (in particular in tumors); thus, corresponding controls (endoplasmic reticulum-related molecules) should be run in studies of isolated membrane vesicles.

In conclusion, exosomes represent the best characterized population within the family of membrane vesicles. However, the isolation, sizing and measurement of MVs and apoptotic bodies remains elusive. There have been significant advances in FC detection and standard isolation of MVs, but pre-analytical factors still remain a challenge. Additionally, quality control of EV preparations is essential prior to functional assays, if describing a specific function of exosomes or MVs.
Conceptual and theoretical issues related to membrane vesicles

The most challenging conceptual issue in the field is the lack of standard terminology and methodology which hampers efficient information flow. International meetings may offer unique opportunities to establish such a consensus.

Current studies test isolated populations of membrane vesicles in vitro. Thus, the effect of a single vesicle type rather than a complex vesicular pattern is assessed (albeit the latter probably reflects in vivo situations more realistically). Combinatorial signaling induced by different vesicles (such as exosomes and MVs) or vesicles in combination with soluble molecules (such as cytokines), has not yet been investigated. Thus, synergistic or additive effects cannot be estimated. Size distribution of vesicles released by apoptotic cells has not yet been systematically explored. Therefore, exclusion of apoptotic bodies $(>1,000 \mathrm{~nm})$ from studies on membrane vesicles may lead to loss of relevant information with respect to EVs. Furthermore, lack of information on local concentrations and half lives of membrane vesicles in tissues prevents drawing conclusions from in vitro functional assays with secreted membrane vesicles.

Finally, the striking structural and functional similarities between exosomes and viruses raise interesting questions. As mentioned earlier, size distributions of exosomes and viruses show a substantial overlap (Fig. 3). Furthermore, both exosomes and many viruses are essentially lipid and protein shells enclosing nucleic acids, and their nucleic acid content is released into the cytosol of the cell. As with viruses, transcription of exosomal RNA has been convincingly shown in cells after uptake of the vesicles [19]. Thus, the description of exosomes may well fit viruses, and the borderline of these two structures might be somewhat blurred. A clear difference is the ability of viruses to replicate inside the infected cells. The intriguing possibility is raised that membrane vesicles (such as exosomes) and viruses may have phylogenic links. HIV-1 and exosomes were reported to share a common glycome arguing for a common origin [85]. It may be hypothesized that certain cell-derived vesicles (carrying enzymes and nucleic acids) might have proven evolutionarily successful to replicate inside cells following their uptake. From this aspect, enveloped viruses such as HIV or influenza virus might be of particular interest, since during their release from cells these viruses acquire an envelope, which is a modified piece of the host's plasma- or internal membrane. It remains an exciting question as to whether viruses like HIV hijack the exosomal dissemination system as suggested [20], a concept that has been refuted in the recent past [86], or they might have taken advantage of cellular vesiculation early during their evolution. Furthermore, it was shown that exosomes from cytomegalovirusinfected (CMV) HUVEC cells contain CMV proteins and 
viral DNA [87], and exosomes from nasopharyngeal carcinoma cells with latent EBV infection, also contain viral proteins as well as virus-specific miRNAs [88].

In the next section, we make an attempt to briefly overview the experimental settings that may serve to investigate the functions of EVs.

\section{Experimental systems to study membrane vesicles}

In vitro modulation of vesicle formation may be achieved by various compounds. The family of potentially targeted pathways and proteins that participate in the release of exosomes and MVs are numerous, and their number is continuously expanding.

Stimulation of certain cell-membrane receptors leads to increased secretion of membrane vesicles. These include P2X(7)R [44, 89, 90] and thrombin receptor [91] or GPVI collagen receptor on platelets [45]. P2X(7)R can be stimulated by ATP or the antimicrobial peptide LL-37 [92], or inhibited by rotterlin [93] and various protein tyrosine kinase antagonists [94]. Resting B cells, T cells, mast cells and reticulocytes can also secrete vesicles after activation of their cell surface receptors [2]. Exosome secretion may be induced by activation of the $\mathrm{T}$ cell receptor or reduced by LPS in dendritic cells [95, 96].

Downstream pathways of cell surface receptors may also be modulated to modify vesicle secretion. Calcium ionophores stimulate vesicle release by elevating intracellular calcium levels in various cells $[97,98]$. Calpeptin, an inhibitor of calmodulin, decreases MV shedding in platelets [99]. Exosome release may also be blocked in melanoma cells by the pretreatment of proton-pump inhibitors, which reduce the acidic milieu [100]. In tumor cells, the GTP binding protein ARF6-GTP activates phospholipase D which recruits extracellular signal-regulated kinase (ERK) to the plasma membrane, where ERK activates myosin light-chain kinase (MLCK). The latter molecule is needed for membrane vesicle secretion; thus, inhibition of ARF6 activation blocks MV shedding [101]. The ceramid pathway can be modulated by inhibition of the synthesizing enzyme, neutral sphingomyelinase [102].

Finally, effector molecules that take part in membrane vesicle formation may also be inhibited. The compound R5421 inhibits scramblase, and reduces MV shedding in reticulocytes [103], while inhibition of the known sheddase, ADAM17, also reduces MV production in platelets [104].

Of note, most proteins involved in vesicle trafficking also have other vital functions, thus blocking them may have detrimental consequences for cells. Strikingly, blocking of Rab27a or Rab27b impairs exosome secretion, without affecting conventional protein secretion [105].

In vivo models suitable for studying vesicle production are almost completely lacking. Scott syndrome, a rare bleeding disorder, is the only known human disease caused by inheritable deficiency of MV production of human platelets as a result of impaired phosphatidyl-serine transmembrane migration and $\mathrm{Ca}^{2+}$-induced phospholipid scrambling [106]. This disease has also been described in a pedigree of German sheepdogs [107], and the gene responsible was linked to canine chromosome 27 [108]. This dog disease could serve as an in vivo animal model to study impaired platelet vesicle secretion.

Human gene polymorphisms may affect membrane vesicle secretion. IL- $1 \beta$ has been shown to be secreted via membrane vesicles after activation of the $\mathrm{P} 2 \mathrm{X}(7)$ receptor and Toll-like receptors in monocytes and macrophages [44, 109]. The gain of function A348T polymorphism of $\mathrm{P} 2 \mathrm{X}(7) \mathrm{R}$ was shown to induce increased IL- $1 \beta$ secretion after LPS priming in monocytes [110], although in this case the route of secretion was not analyzed. However, the G496A loss of function mutation of the same gene was reported to decrease both secretion of IL- $1 \beta$ and shedding of L-selectin [111]. Polymorphisms of other genes, encoding for proteins that take part in MV formation and secretion, offer possibilities for studying membrane vesicles. Thus, polymorphisms and mutations of genes that influence EV formation may serve as valuable tools to study vesicle formation processes.

On the other hand, membrane vesicle research may also benefit from lessons of in vivo experimental models of impaired vesicle secretion. Various knock-out mice may serve as attractive mammalian candidates to study deficiency of proteins that participate in membrane vesicle formation. For instance, leukocytes of P2X(7)R-deficient mice are characterized by reduced shedding of L-selectin, and decreased secretion of IL- $1 \beta$ in response to LPS and ATP [112]. Tumor suppressor-activated pathway 6 (TSAP6)-deficient mice show microcytic anemia, with abnormal reticulocyte maturation and deficient transferrin receptor downregulation, features which are all dependent on exosome secretion. Exosome production is also impaired in TSAP6 null cells [113].

Mice, genetically deficient in the clearance of membrane vesicles (e.g., phosphatidyl-serine knockout mice [114] or $\mathrm{T}$ cell immunoglobulin and mucin domain-containing protein 4 (TIM4)-deficient mice [115]) represent another type of in vivo experimental system to study membrane vesicles. The significance of such an in vivo system is supported by the observation that TIM4-deficient mice exhibit autoimmunity and $\mathrm{T}$ and $\mathrm{B}$ cell hyperactivity [115]. Recently, Tyro3/Axl/Mer (TAM) signaling has been implicated in the 'homeostatic phagocytosis' of apoptotic cells and membranes [116]. Similarly to TIM4-deficient mice, TAM-deficient mice develop autoimmunity [117]. The human autoimmune disease systemic lupus erythematosus (SLE) may offer another in vivo system to 
investigate membrane vesicles, as SLE is characterized by an impaired clearance of apoptotic bodies [118-123].

Comprehensive meta-analysis of proteomic studies on different types of membrane vesicles

In contrast to sporadic publications on membrane vesicle lipidomics [124-127], metabolomics [128] or glycomics [85], information regarding the protein composition of EVs may be readily extracted from numerous published proteomic studies as well as from a database [129]. In order to obtain a reliable and representative set of proteins identified in exosomes, we filtered the ExoCarta database [129] for proteomic studies, and selected only data from sources in which human exosomes were purified by density gradient ultracentrifugation [126, 129-133]. Unlike in the case of exosomes, there is no comprehensive database for proteomic data regarding MVs. While the diversity of tissue types analyzed by exosome studies makes the obtained dataset representative for these structures, at present there is a clear overrepresentation of data concerning plateletderived MVs in the literature. In the MV dataset, we included data from proteomic studies on human platelet or plasma-derived MVs, in which protein data were supplied in a clearly accessible format $[128,134-136]$. Subcellular localization of proteins can be readily analyzed using the annotations of the SwissProt/UniProt database [137, 138]. Although the proteomic studies from which the protein datasets were extracted also investigated the subcellular localization of molecules, the different methods of vesicle isolation and analysis interfered with the comparison of the results from individual studies.

One may anticipate that the subcellular localization of a protein in an intact cell is in concordance with the possible localization in a membrane vesicle. Since both exosomes and MVs are considered to consist of cytoplasm enclosed by a lipid bilayer, it was interesting to find a notable portion of nuclear proteins in both vesicle populations (Fig. 5). Given that platelets have no nuclei, the presence of nuclear proteins in MVs isolated from blood plasma supports the recent observation that circulating MVs are of megakaryocyte rather than platelet origin [83]. Nuclear proteins may originate from the preparation methods, as centrifugation may also pellet apoptotic or necrotic materials (apoptotic bodies, nuclear fragments or nucleosomal complexes) together with MVs. Dean et al. demonstrated that nuclear proteins are not evenly distributed in all size fractions of platelet-derived MVs [136]. Of note, cytosolic proteins, known to undergo nuclear translocation, may have also increased the frequency of nuclear proteins, as we included proteins in all their possible subcellular localizations (according to SwissProt-UniProt annotations) when generating Fig. 5. In contrast to the unexpectedly
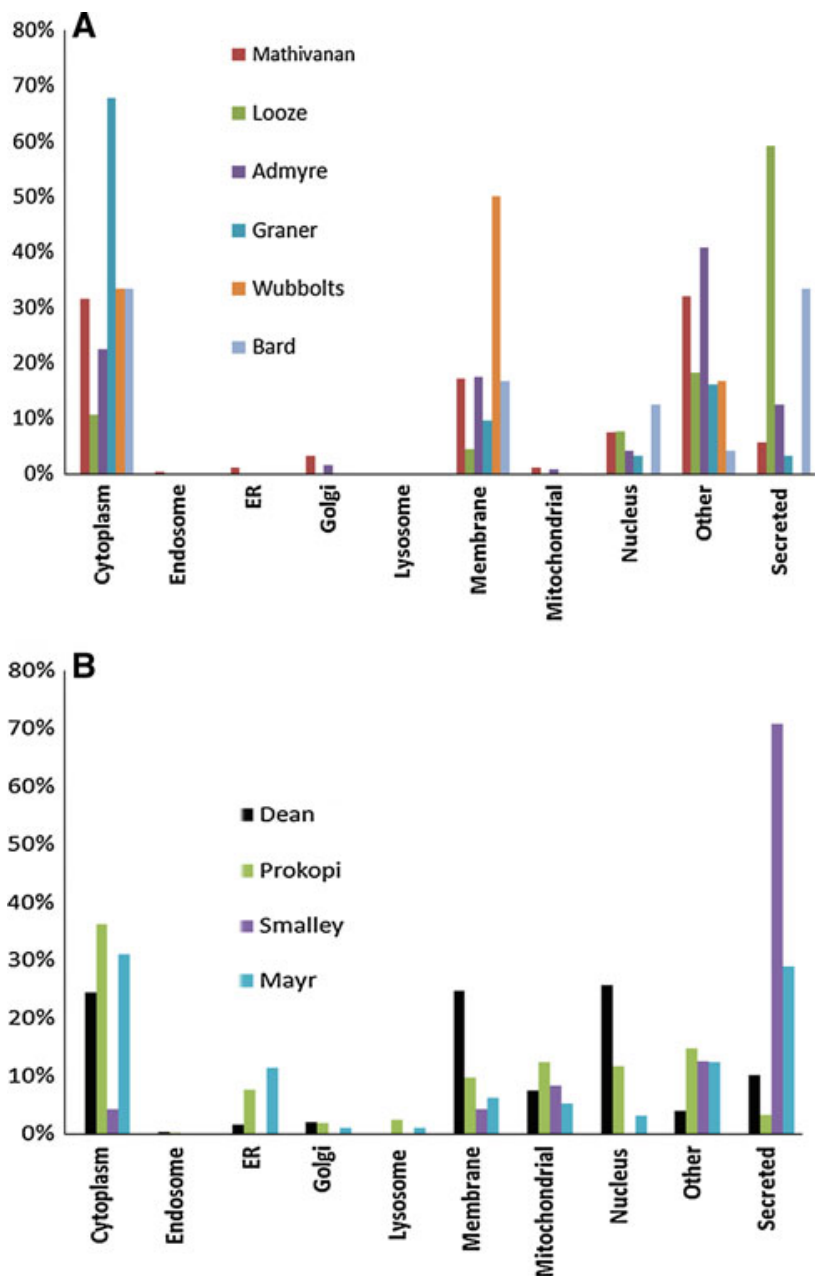

Fig. 5 Subcellular localization of proteins identified in exosomes (a) and MVs (b) The published proteomic studies are indicated by the name of the first author

high ratio of nuclear proteins found in MVs, exosomes contained only limited amounts of nuclear proteins. Membrane-associated proteins, on the other hand, constituted the major fraction of exosomal proteins.

One of the possible functions of membrane vesicles is contributing to non-classical leaderless secretion of proteins such as IL-1 $\beta$ [139]. Taking advantage of the recently available prediction tools to determine which proteins are likely to undergo leaderless secretion [140], we used the SecretomeP 2.0 software from CBS [141] on a dataset previously filtered for cytoplasmic proteins. All membrane proteins are likely to contain a signal sequence and thus avoid leaderless secretion. Using this prediction tool, we analyzed data obtained in six studies on exosomes and four studies on MVs. From all cytoplasmic proteins in each dataset, around $30 \%$ were predicted to be secreted nonclassically. The remaining molecules (such as cytoskeletal proteins) could contribute to a protective shell stabilizing vesicular structure, and may carry targeting information. 
Since IL-1 $\beta$, for example, plays a crucial role in regulating immune responses, it is critical to achieve the right concentration at the right site. Although it is degraded rapidly in human plasma (its half-life is 6 min [142]), it might be preserved for a longer time inside vesicles, thus enabling it to act systematically or locally, but distant from the site of its production. For IL- $1 \beta$, the majority of leaderless secretion has been reported to occur by exosomes [143].

The fact that molecules, predicted to undergo leaderless secretion, were not detected in substantial amounts in vesicles might either suggest an alternative route for nonclassical secretion (other than by secretion of membrane vesicles), or may result from limitations of current prediction tools. Indeed, transporters have also been suggested to be involved in leaderless protein secretion [144], representing a minor alternative to release by exosomes.

When exosome- and MV-associated proteins were analyzed for major biological functions by Ingenuity Pathway Analysis (IPA; Ingenuity Systems, Mountain View, CA, USA), in the case of both vesicle populations, cellular movement, cell-to-cell signaling, tissue development and cancer were among the top associated biological functions. The function "cell death" was associated more with MVs than with exosomes (in agreement with the observation that release of MVs is induced during apoptosis). In contrast to exosomes, MV proteins were found to be associated with inflammation, and this function was ranked 10th in the case of MVs, whereas it was ranked only 30th for exosomes (data not shown).

According to the IPA software, many of the key molecules implicated in viral entry into cells are also detectable in exosomes (Fig. 6a). These molecules expressed by both exosomes and cells bind a variety of viruses, like SV40, Filo-, Coxsackie's-, Echo-, and Arena viruses and even HIV1. The presence of numerous virus binding proteins in exosomes is in line with the fact that virus entry via endocytic pathways is a well-known attribute to exosomes, reviewed recently by Izquierdo-Useros et al. [145]. Out of all biological pathways in the IPA knowledge base, the most adequate fit of MV proteins appeared to be integrinmediated signal transduction (Fig. 6b). The integrin pathway is involved in regulating cell shape and motility in response to changes in the extracellular environment. MV proteins implicated in this pathway include actin, talin and vinculin, molecules involved in regulating cell shape and cellular movement. The significance of the abundant virus binding proteins in exosomes and MV molecules involved in integrin signaling remains to be elucidated experimentally.

Top canonical functions, identified by IPA software in association with exosomes and MVs, are included in Table 2. While many of the identified pathways revealed known features of membrane vesicles, germ cell-Sertoli cell signaling in exosomes, however, seems to represent an unexpected pathway. During spermatogenesis, actin-based adherens junctions at the interface of Sertoli and germ cells undergo extensive restructuring. This facilitates germ cell movement across the epithelium. The dynamics of these junctions are regulated by the integrin/RhoB/ROCK/LIMK pathway [146]. The clear nature of this pathway in the case of exosomes remains to be established, and at this point we cannot exclude the possibility that it may be an issue related to the in silico analysis rather than a real biological process existing in exosomes.

\section{Medical implications of the extracellular vesicles}

In the present review, we have described the diverse constituents of the extracellular vesicular compartment. The ubiquitous formation of membrane vesicles allows the clinician to exploit their diagnostic value in various diseases (Table 3) and conditions. Exosomes are smaller, but can serve as tumor markers. MVs are investigated thoroughly as diagnostic tools due to their larger size and accessibility in several biological fluids. Most groups have focused on blood-derived MVs. Here, we discuss the most widely studied endothelial- and platelet-derived MVs as well as some recent advances of tumor vesicle-based diagnostic studies.

\section{Endothelial MVs (eMVs)}

Endothelial cells can release exosomes, endothelial MVs (in the literature often also referred to as EMPs) and apoptotic bodies [24]. eMVs are formed in vitro after stimulation with LPS, reactive oxygen species and various cytokines [24]. They are detectable in human blood plasma by FC using endothelial cell-specific markers (CD54, CD62E, CD62P, CD31, CD106, CD105, CD144, CD146) [24]. Despite the limitations of FC, eMVs are considered to be markers of inflammation, endothelial injury and endothelial dysfunction [147-149]. As endothelial dysfunction is a well-known predictor of future cardiovascular diseases, eMVs could be used as biomarkers of vascular health.

eMVs are elevated in the blood plasma of patients with acute and chronic vascular disorders, including acute coronary syndrome [150], severe hypertension [151], endstage renal failure [149] and pulmonary arterial hypertension [152] (for a review, see [153]) (Table 3). eMVs have a controversial role in the pathogenesis of vascular diseases [18]: eMVs may contribute to vascular injury and they are capable of inducing endothelial cell activation, impairing vasorelaxation [154], and promoting arterial stiffness. Furthermore, phosphatidyl-serine and/or tissue factor positive eMVs promote coagulation and 

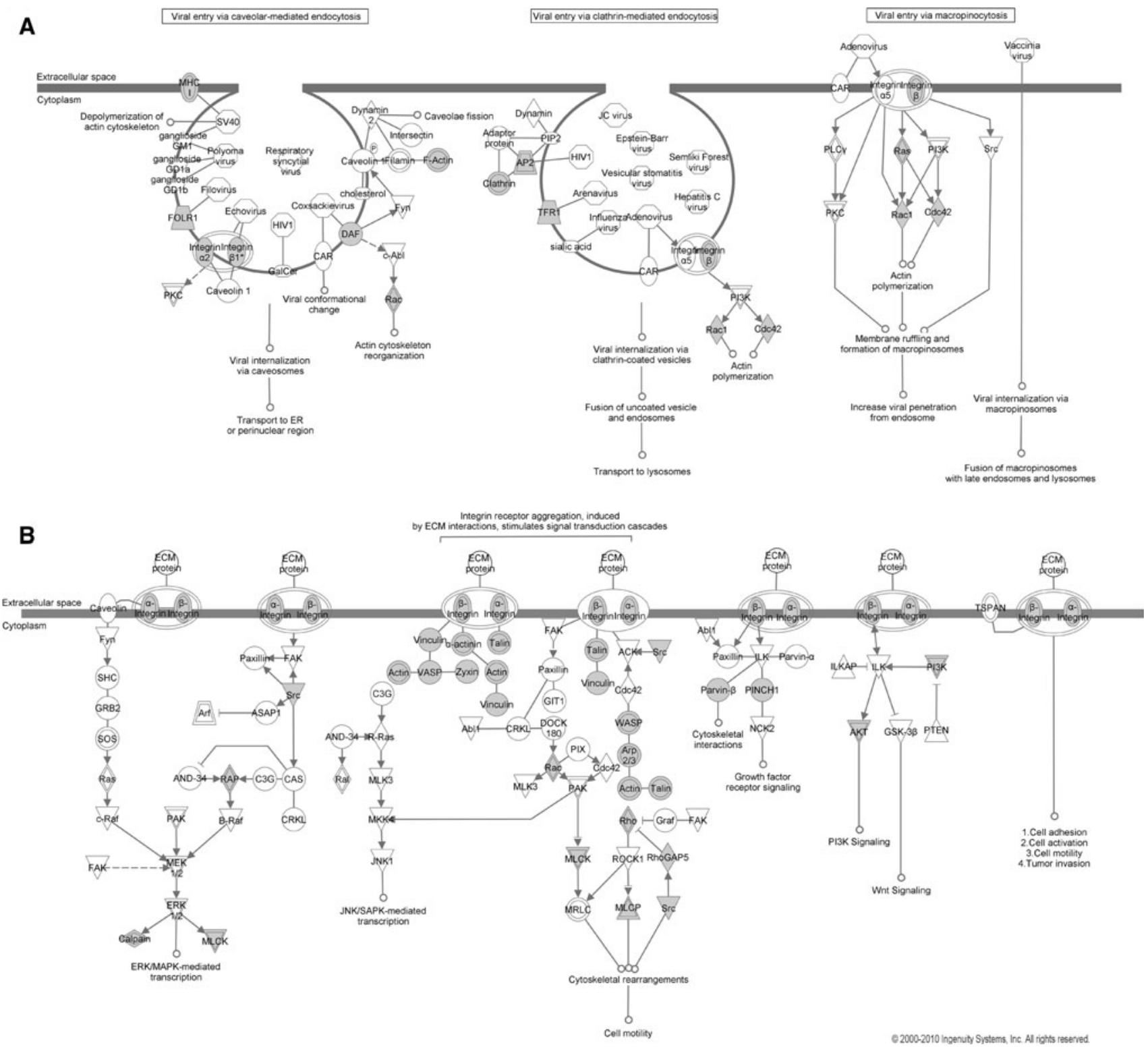

Fig. 6 Ingenuity Pathway Analysis (IPA) of data from meta-analyses of published proteomic studies on exosomes and microvesicles. a Molecules implicated in viral entry by caveola- and clathrinmediated endocytosis as well as by macropinocytosis. Shaded symbols represent molecules identified in exosomes. As shown, several exosomal proteins are present in the IPA knowledgebase as molecules that facilitate the entry of different viruses. b Molecules involved in integrin signaling. Shaded symbols represent published microvesicle-associated proteins as key participants of integrin signaling thrombosis. On the other hand, it has been shown that eMVs may induce angiogenesis or promote endothelial cell survival [24].

\section{Platelet MVs (pMVs)(Fig. 4)}

The majority of circulating MVs in the blood plasma are derived from platelets during platelet activation or, as suggested recently, from megakaryocytes [83]. In vitro, pMVs are formed during stimulation of platelets with collagen, thrombin or ADP. Shear stress and agitation also induces pMV formation. pMVs are easily detected by FC using CD41, CD42, CD61, and CD62 markers. Similarly to eMVs in endothelial activation, pMVs are considered as platelet activation markers. Therefore, numerous diseases are characterized by elevated levels of pMVs (Table 3), including cardiovascular diseases, autoimmune diseases [62] and type II diabetes. pMVs may also expose phosphatidyl-serine and tissue factor, and they may also contribute to the pathogenesis of vascular diseases due to 
Table 2 Top vesicle-associated canonical pathways identified by Ingenuity Pathway Analysis

\begin{tabular}{|c|c|c|c|c|c|}
\hline \multicolumn{3}{|l|}{ MPs/MVs } & \multicolumn{3}{|l|}{ Exosome } \\
\hline Canonical pathway & $P$ value & Ratio & Canonical pathway & $P$ value & Ratio \\
\hline Actin cytoskeleton signaling & $6.05 \mathrm{E}-14$ & $38 / 238$ & Germ cell-Sertoli cell junction signaling & $1.20 \mathrm{E}-23$ & $45 / 168$ \\
\hline Integrin signaling & $5.18 \mathrm{E}-11$ & $32 / 205$ & Integrin signaling & $1.65 \mathrm{E}-21$ & $47 / 205$ \\
\hline RhoA signaling & $4.53 \mathrm{E}-09$ & $21 / 110$ & Caveolar mediated endocytosis signaling & $2.92 \mathrm{E}-21$ & $30 / 85$ \\
\hline Caveolar mediated endocytosis signaling & $1.12 \mathrm{E}-08$ & $17 / 85$ & Virus entry via endocytic pathways & $1.58 \mathrm{E}-20$ & $32 / 100$ \\
\hline Acute phase response signaling & $2.21 \mathrm{E}-08$ & $26 / 183$ & Ephrin receptor signaling & $2.42 \mathrm{E}-20$ & $43 / 199$ \\
\hline
\end{tabular}

The $P$ value is calculated using the right-tailed Fisher Exact Test. It is a measure of the likelihood that the association between a set of analyzed molecules and a given pathway is due to random chance. The "ratio" expresses the fraction of molecules fitting a given pathway within an analyzed dataset and the total number of molecules known to be associated with that pathway in Ingenuity's knowledge base

Table 3 Diagnostic or prognostic alterations of the extracellular vesicles

\begin{tabular}{|c|c|c|c|}
\hline Disorders & Type of vesicles & $\begin{array}{l}\text { Alterations of the extracellular } \\
\text { vesicular compartment }\end{array}$ & References \\
\hline \multicolumn{4}{|l|}{ Autoimmune diseases } \\
\hline Systemic lupus erythematosus & pMVs and eMVs & Elevated levels of pMVs and eMVs in blood plasma & {$[52,168]$} \\
\hline Anti-phospholipid syndrome & pMVs and eMVs & Elevated levels of eMVs and pMVs in blood plasma & {$[169,170]$} \\
\hline Rheumatoid arthritis & pMVs & $\begin{array}{l}\text { Elevated levels of pMVs in blood plasma, elevated levels of annexin } \\
\mathrm{V}^{+} \text {MVs and pMVs in synovial fluid }\end{array}$ & $\begin{array}{l}{[38,45,52,} \\
\quad 171 \\
172]\end{array}$ \\
\hline Systemic sclerosis & pMVs, eMVs and lMVs & Elevated levels of pMVs, eMVs and IMVs in blood plasma & {$[173,174]$} \\
\hline Vasculitis & pMVs, eMVs and lMVs & $\begin{array}{l}\text { Increased number of pMVs and lMVs in acute vasculitis and increased } \\
\text { numer of pMVs and eMVs in systemic vasculitis }\end{array}$ & {$[175-177]$} \\
\hline Type 1 diabetes mellitus & pMVs, eMVs & $\begin{array}{l}\text { Increased number of eMVs and pMVs, increased total MV } \\
\text { procoagulant activity }\end{array}$ & [178] \\
\hline Multiple sclerosis & pMVs, eMVs & $\begin{array}{l}\text { Elevated levels of pMVs and elevated levels of eMVs during } \\
\text { exacerbation }\end{array}$ & {$[179,180]$} \\
\hline \multicolumn{4}{|l|}{ Cardiovascular diseases } \\
\hline Acute coronary syndrome & pMVs, eMVs & $\begin{array}{l}\text { High levels of procoagulant eMVs and pMVs are present in the } \\
\text { circulating blood of patients. High eMV level was associated with } \\
\text { high-risk angiographic lesions in patients with acute coronary } \\
\text { syndromes. Levels of eMVs may predict future cardiovascular } \\
\text { events in patients at high risk for congestive heart failure }\end{array}$ & $\begin{array}{c}{[150,181-} \\
185]\end{array}$ \\
\hline Hypertension & eMVs, pMVs & $\begin{array}{l}\text { Levels of eMVs and pMVs correlate with blood pressure. } \\
\text { Hypertensive patients with microalbuminuria have higher levels of } \\
\text { eMVs compared to hypertensive patients without microalbuminuria }\end{array}$ & {$[151,186]$} \\
\hline Pulmonary hypertension & pMVs, eMVs, lMVs & $\begin{array}{l}\text { eMVs predict severity of pulmonary hypertension. Elevated levels of } \\
\text { pMVs, eMVs and lMVs predict vascular inflammation and } \\
\text { hypercoagulability }\end{array}$ & $\begin{array}{c}{[152,187} \\
188]\end{array}$ \\
\hline Congestive heart failure & eMVs & $\begin{array}{l}\text { Apoptotic eMVs are elevated in patients with congestive heart failure. } \\
\text { Furthermore, the levels of eMVs correlate with NYHA functional } \\
\text { classes. Patients undergoing heart transplantation due to heart } \\
\text { failure show altered phenotypes of eMVs }\end{array}$ & [189-191] \\
\hline $\begin{array}{l}\text { Deep vein thrombosis (DVT) } \\
\text { and venous thromboembolism }\end{array}$ & eMVs, pMVs & $\begin{array}{l}\text { pMVs and eMVs are elevated in patients with DVT. Total MV count } \\
\text { may serve as novel markers for DVT. Circulating MVs and pMVs } \\
\text { are elevated in patients with acute pulmonary embolism }\end{array}$ & [192-194] \\
\hline Buerger's disease & pMVs & pMVs are markers of exacerbation & [195] \\
\hline Atherosclerosis & 1MVs, pMVs & $\begin{array}{l}\text { CD11a positive IMVs predict subclinical atherosclerosis. pMVs are } \\
\text { elevated in individuals with carotis atherosclerosis }\end{array}$ & {$[196,197]$} \\
\hline
\end{tabular}


Table 3 continued

\begin{tabular}{|c|c|c|c|}
\hline Disorders & Type of vesicles & $\begin{array}{l}\text { Alterations of the extracellular } \\
\text { vesicular compartment }\end{array}$ & References \\
\hline Cerebrovascular disorders & $\begin{array}{l}\text { pMVs, eMVs, IMVs } \\
\text { and erythrocyte MVs }\end{array}$ & $\begin{array}{l}\text { pMVs are elevated in transient ischaemic attacks, lacunar infarcts and } \\
\text { multiinfarct dementias. pMVs, eMVs, lMVs and erythrocyte MVs } \\
\text { are elevated in patients with subarachnoid hemorrhage and are } \\
\text { markers of vasospasm. Circulating eMV phenotypic profiles reflect } \\
\text { distinct phenotypes of cerebrovascular disease }\end{array}$ & {$[198-202]$} \\
\hline \multicolumn{4}{|l|}{ Hematologic diseases } \\
\hline $\begin{array}{l}\text { Paroxysmal nocturnal } \\
\text { haemoglobinuria }\end{array}$ & eMVs & Elevated levels of eMVs & [203] \\
\hline Sickle cell disease & $\begin{array}{l}\text { eMVs, pMVs, } \\
\text { erythrocyte-MVs, }\end{array}$ & $\begin{array}{l}\text { Elevated levels of total MVs, eMVs, pMVs and erythrocyte MVs, } \\
\text { particularly in sickle cell crisis }\end{array}$ & [204] \\
\hline $\begin{array}{l}\text { Immune thrombocytopenic } \\
\text { purpura (ITP) }\end{array}$ & pMVs & $\begin{array}{l}\text { pMVs are elevated in patients with acute ITP and decreased in chronic } \\
\text { ITP }\end{array}$ & [205] \\
\hline $\begin{array}{l}\text { Thrombotic } \\
\text { thrombocytopenic purpura }\end{array}$ & eMVs & Elevated levels of eMVs & [206] \\
\hline \multicolumn{4}{|l|}{ Cancer } \\
\hline Lung adenocarcinoma & Exosomes & Elevated level of exosomes and miRNA in blood plasma of patients. & {$[163]$} \\
\hline Glioblastoma & $\begin{array}{l}\text { Tumor-derived } \\
\text { exosomes }\end{array}$ & $\begin{array}{l}\text { Tumor-specific EGFRvIII was detected in serum exosomes from } \\
\text { patients }\end{array}$ & [159] \\
\hline Ovarian cancer & $\begin{array}{l}\text { Tumor-derived } \\
\text { exosomes }\end{array}$ & $\begin{array}{l}\text { Exosomal miRNA from ovarian cancer patients exhibited distinct } \\
\text { profiles compared to patients with benign disease }\end{array}$ & {$[161]$} \\
\hline Prostate cancer & $\begin{array}{l}\text { Tumor-derived } \\
\text { exosomes in blood } \\
\text { and urine }\end{array}$ & $\begin{array}{l}\text { Detection of tumor-specific exosomes in blood could be used as a } \\
\text { screening test. Urinary exosomes contain biomarkers for prostate } \\
\text { cancer }\end{array}$ & $\begin{array}{l}{[164,207,} \\
208]\end{array}$ \\
\hline Colorectal cancer & $\begin{array}{l}\text { Tumor-derived } \\
\text { exosomes }\end{array}$ & $\begin{array}{l}\text { Detection of tumor-specific exosomes in blood could be used as a } \\
\text { screening test }\end{array}$ & {$[165]$} \\
\hline Gastric cancer & pMVs & $\begin{array}{l}\text { pMVs are markedly increased in patients with stage IV disease and } \\
\text { might be useful for identifying metastatic gastric patients. }\end{array}$ & [209] \\
\hline Melanoma & Exosomes & Elevated CD63 and caveolin 1 on exosomes & {$[210]$} \\
\hline Oral cancer & Exosomes & $\begin{array}{l}\text { Sera of patients with active oral squamous cell carcinoma contain } \\
\mathrm{FasL}^{+} \text {exososmes }\end{array}$ & [211] \\
\hline $\begin{array}{l}\text { Cancer associated } \\
\text { thrombosis }\end{array}$ & $\mathrm{TF}^{+} \mathrm{MVs}$ & $\begin{array}{l}\mathrm{TF}^{+} \mathrm{MVs} \text { are elevated in patients with colorectal carcinoma, multiple } \\
\text { myeloma, breast and pancreatic adenocarcinoma }\end{array}$ & [212-214] \\
\hline \multicolumn{4}{|l|}{ Other diseases } \\
\hline Alzheimer's disease & pMVs & pMVs carry amyloid $\beta$ on their surface & [215] \\
\hline Type 2 diabetes mellitus & pMVs, $1 M V s$ & $\begin{array}{l}\text { Elevated levels of pMVs, especially in patients with clinically } \\
\text { apparent atherosclerosis, elevated percentage of } \mathrm{TF}^{+} \mathrm{MVs} \text {. Patients } \\
\text { with nephropathy have higher number of monocyte-MVs }\end{array}$ & [216-219] \\
\hline Metabolic syndrome & $\begin{array}{l}\text { MVs exposing TF, } \\
\text { eMVs }\end{array}$ & $\begin{array}{l}\text { The level of TF exposing MVs correlate with the components of } \\
\text { metabolic syndrome. Pioglitazon has been shown to reduce eMV } \\
\text { levels in patients with metabolic syndrome }\end{array}$ & $\begin{array}{l}{[218,220} \\
221]\end{array}$ \\
\hline End-stage renal disease & eMVs, PMVs & $\begin{array}{l}\text { Total annexin } \mathrm{V}^{+} \mathrm{MVs} \text {, pMVs, eMVs are elevated in patients with } \\
\text { end-stage renal disease and patients with hemodialysis. eMVs } \\
\text { predict vascular dysfunction and represent a marker of endothelial } \\
\text { dysfunction }\end{array}$ & {$[149,222]$} \\
\hline Obstructive sleep apnoe & pMVs, lMVs, eMVs & $\begin{array}{l}\text { Total annexin } \mathrm{V}^{+} \mathrm{MVs} \text {, pMVs, lMVs and eMVs are elevated in } \\
\text { patients }\end{array}$ & {$[223,224]$} \\
\hline Preeclampsia & $\begin{array}{l}\text { eMVs, lMVs, pMVs, } \\
\text { synctiotrophoblast } \\
\text { MVs. }\end{array}$ & Elevated levels of eMVs, syncytiotrophoblast MVs pMVs and IMVs & {$[225-230]$} \\
\hline Sepsis & $\begin{array}{l}\text { pMVs, eMVs, } \\
\text { granulocyte MVs }\end{array}$ & $\begin{array}{l}\text { pMVs and eMVs are elevated in septic shock, but their elevation } \\
\text { predicts favorable outcomes. Patients with meningococcal sepsis } \\
\text { have elevated numbers of pMVs and granulocyte-derived MVs }\end{array}$ & [231-233] \\
\hline
\end{tabular}


their highly thrombogenic potential. Most interestingly, not only blood plasma but also synovial fluid from RA patients contain high amounts of pMVs [45] and activate synovial fibroblasts via their IL-1 content. In accordance with these results, numerous publications have demonstrated the elevated levels of pMVs in the blood plasma of patients with various rheumatic diseases (Table 3) [62]. pMVs are characterized by a highly adhesive surface and may bind to endothelial cells, leukocytes and matrix molecules [155]. Furthermore, adherent MVs may also transfer GPIIb/IIIa to cells, including neutrophils [156], leading to cell activation. In summary, pMVs possibly represent novel players in the network of inflammation and autoimmunity.

\section{Tumor-derived membrane vesicles}

Tumors are characterized by secretion of various forms of membrane vesicles constitutively. These comprise exosomes [157], MVs [158] and apoptotic bodies (as a result of increased apoptosis in tumors). Released membrane vesicles contain tumor-specific antigens on their surface, e.g., Her2/Neu mesothelin, MelanA/Mart-1, CEA, HER-2, and EGFRvIII [19, 157, 159]. Furthermore, membrane vesicles from cancer cells contain RNA. Several reports indicate that miRNA-based identification of cancer leads to a reliable characterization of the origin and development of tumors [160, 161]. miRNAs, circulating in serum, plasma, saliva and breast milk, are resistant to degradation [160], and therefore it was suggested that miRNAs are protected by lipid or lipoprotein complexes [162]. As certain miRNAs are characteristic for tumors, their presence within tumor-derived exosomes and MVs may serve as novel biomarkers of cancer. The exosomal miRNA levels or patterns showed correlation with lung adenocarcinoma [163], glioblastoma [159] and ovarian cancer [161]. Recently, a EV-based diagnostic platform has been developed for the diagnosis of prostate cancer [164]. In this study, prostate tumor-specific vesicles in blood plasma have been identified using simultaneous detection of prostate-, tumor- and exosome-specific markers. Using this "biosignature" of prostate cancer EVs, diagnostic specificity and sensitivity of 83 and $90 \%$, respectively, have been reached. This group also analyzed EVs from colorectal cancer patients in blood plasma, and diagnostic sensitivity and specificity of 85 and $85 \%$, respectively, have been reported [165]. These data suggest that tumorderived membrane vesicles could open a new era in cancer screening and diagnostics in the near future. The technology used in these studies, however, does not specifically purify exosomes or MVs [166], yet appears to be diagnostically useful. Thus, careful isolation of given EV subpopulations in a clinical monitoring assay may be less important than previously thought.
Importantly, EVs (in particular exosomes) have been recently suggested to serve as novel therapeutic agents against cancer. Ongoing Phase I and Phase II trials and therapeutic strategies have been reviewed recently by Chaput and Thery [22]. Moreover, EVs may serve as novel promising vectors for future gene therapy [167].

\section{Conclusions}

Based on recent convergent data, we propose that there exists a previously poorly recognized, complex and dynamic extracellular vesicular compartment. Depending on the functional state of cells in the tissues, the composition of this compartment may change spatially and temporarily. The plasticity of the compartment may enable adaptation to altered conditions, and its evolutionarily conserved nature suggests efficient and vital biological functions of this compartment. At present, we are still far from fully appreciating the biological significance of EVs. Collectively, constituents of this compartment represent large membrane surface areas, and their amount in the extracellular space might be best appraised on the basis of their membrane lipid content or lipid/protein ratio. Biological systems in which vesicles are released into large volumes of extracellular fluid, such as blood plasma or tissue culture medium (where they are not taken up immediately by surrounding cells), provide some clues about the magnitude of vesicle formation and the efficacy of clearance in tissues. Their molecular composition shows striking similarities including the shared presence of cytoskeletal proteins, membrane lipid composition and externalized phosphatidylserine, just to mention a few examples. Size distribution is another area of overlap. Even though not characterized in detail, it may be hypothesized that uptake and removal by cells occurs by similar or identical molecular mechanisms.

Similarly to cytokines that constitute a network of communication, EVs may also exert their functions in a network, which is acting in a specific context with many other players. The long list of medical implications, affecting different organs, justifies systems biology approaches to study EVs.

Understanding of this compartment challenges the current paradigms concerning the mechanisms of intercellular communication and immune regulation. It may also open new perspectives in translational medicine both in diagnostics and therapy.

Acknowledgments This work was supported by grants OTKA K73247, 84043, 77537 and 83857.

Open Access This article is distributed under the terms of the Creative Commons Attribution Noncommercial License which 
permits any noncommercial use, distribution, and reproduction in any medium, provided the original author(s) and source are credited.

\section{References}

1. van der Pol E, Hoekstra AG, Sturk A, Otto C, van Leeuwen TG, Nieuwland R (2010) Optical and non-optical methods for detection and characterization of microparticles and exosomes. J Thromb Haemost 8(12):2596-2607

2. Thery C, Ostrowski M, Segura E (2009) Membrane vesicles as conveyors of immune responses. Nat Rev Immunol 9(8):581-593

3. Silverman JM, Reiner NE (2011) Exosomes and other microvesicles in infection biology: organelles with unanticipated phenotypes. Cell Microbiol 13(1):1-9

4. Rivera J, Cordero RJ, Nakouzi AS, Frases S, Nicola A, Casadevall A (2010) Bacillus anthracis produces membrane-derived vesicles containing biologically active toxins. Proc Natl Acad Sci USA 107(44):19002-19007

5. Islam A, Jones H, Hiroi T, Lam J, Zhang J, Moss J, Vaughan M, Levine SJ (2008) cAMP-dependent protein kinase A (PKA) signaling induces TNFR1 exosome-like vesicle release via anchoring of PKA regulatory subunit RIIbeta to BIG2. J Biol Chem 283(37):25364-25371

6. Marzesco AM, Janich P, Wilsch-Bräuninger M, Dubreuil V, Langenfeld K, Corbeil D, Huttner WB (2005) Release of extracellular membrane particles carrying the stem cell marker prominin-1 (CD133) from neural progenitors and other epithelial cells. J Cell Sci 118(Pt 13):2849-2858

7. Stinchcombe J, Bossi G, Griffiths GM (2004) Linking albinism and immunity: the secrets of secretory lysosomes. Science 305(5680):55-59

8. Davis DM (2007) Intercellular transfer of cell-surface proteins is common and can affect many stages of an immune response. Nat Rev Immunol 7(3):238-243

9. Gasser O, Schifferli JA (2004) Activated polymorphonuclear neutrophils disseminate anti-inflammatory microparticles by ectocytosis. Blood 104(8):2543-2548

10. Bretting H, Konigsmann K (1979) Investigations on the lectinproducing cells in the sponge Axinella polypoides (Schmidt). Cell Tissue Res 201(3):487-497

11. Powell JJ, Thoree V, Pele LC (2007) Dietary microparticles and their impact on tolerance and immune responsiveness of the gastrointestinal tract. Br J Nutr 98(Suppl 1):59-63

12. Bona C, Robineaux R, Anteunis A, Heuclin C, Astesano A (1973) Transfer of antigen from macrophages to lymphocytes. II. Immunological significance of the transfer of lipopolysaccharide. Immunology 24 (5):831-840

13. Rechavi O, Goldstein I, Kloog Y (2009) Intercellular exchange of proteins: the immune cell habit of sharing. FEBS Lett 583(11):1792-1799

14. Trams EG, Lauter CJ, Salem N Jr, Heine U (1981) Exfoliation of membrane ecto-enzymes in the form of micro-vesicles. Biochim Biophys Acta 645(1):63-70

15. Harding C, Heuser J, Stahl P (1983) Receptor-mediated endocytosis of transferrin and recycling of the transferrin receptor in rat reticulocytes. J Cell Biol 97(2):329-339

16. Pan BT, Teng K, Wu C, Adam M, Johnstone RM (1985) Electron microscopic evidence for externalization of the transferrin receptor in vesicular form in sheep reticulocytes. J Cell Biol 101(3):942-948

17. Hurley JH, Boura E, Carlson LA, Różycki B (2010) Membrane budding. Cell 143(6):875-87
18. Valadi H, Ekstrom K, Bossios A, Sjostrand M, Lee JJ, Lotvall JO (2007) Exosome-mediated transfer of mRNAs and microRNAs is a novel mechanism of genetic exchange between cells. Nat Cell Biol 9(6):654-659

19. Al-Nedawi K, Meehan B, Micallef J, Lhotak V, May L, Guha A, Rak J (2008) Intercellular transfer of the oncogenic receptor EGFRvIII by microvesicles derived from tumour cells. Nat Cell Biol 10(5):619-624

20. Izquierdo-Useros N, Naranjo-Gomez M, Archer J, Hatch SC, Erkizia I, Blanco J, Borras FE, Puertas MC, Connor JH, Fernandez-Figueras MT, Moore L, Clotet B, Gummuluru S, Martinez-Picado J (2009) Capture and transfer of HIV-1 particles by mature dendritic cells converges with the exosomedissemination pathway. Blood 113(12):2732-2741

21. Raposo G, Nijman HW, Stoorvogel W, Liejendekker R, Harding CV, Melief CJ, Geuze HJ (1996) B lymphocytes secrete antigenpresenting vesicles. J Exp Med 183(3):1161-1172

22. Chaput N, Thery C (2010) Exosomes: immune properties and potential clinical implementations. Semin Immunopathol (in press)

23. Mathivanan S, Ji H, Simpson RJ (2010) Exosomes: extracellular organelles important in intercellular communication. J Proteomics 73(10): 1907-1920

24. Dignat-George F, Boulanger CM (2011) The many faces of endothelial microparticles. Arterioscler Thromb Vasc Biol 31(1):27-33

25. Thery C, Amigorena S, Raposo G, Clayton A (2006) Isolation and characterization of exosomes from cell culture supernatants and biological fluids. Curr Protoc Cell Biol (Chapter 3:Unit 3) 22

26. Fevrier B, Raposo G (2004) Exosomes: endosomal-derived vesicles shipping extracellular messages. Curr Opin Cell Biol 16(4):415-421

27. Anand PK (2010) Exosomal membrane molecules are potent immune response modulators. Commun Integr Biol 3(5):405-408

28. Lotvall J, Valadi H (2007) Cell to cell signalling via exosomes through esRNA. Cell Adh Migr 1(3):156-158

29. Belting M, Wittrup A (2008) Nanotubes, exosomes, and nucleic acid-binding peptides provide novel mechanisms of intercellular communication in eukaryotic cells: implications in health and disease. J Cell Biol 183(7):1187-1191

30. Admyre C, Telemo E, Almqvist N, Lotvall J, Lahesmaa R, Scheynius A, Gabrielsson S (2008) Exosomes-nanovesicles with possible roles in allergic inflammation. Allergy 63(4): 404-408

31. Lakkaraju A, Rodriguez-Boulan E (2008) Itinerant exosomes: emerging roles in cell and tissue polarity. Trends Cell Biol 18(5):199-209

32. Simpson RJ, Lim JW, Moritz RL, Mathivanan S (2009) Exosomes: proteomic insights and diagnostic potential. Expert Rev Proteomics 6(3):267-283

33. Simons M, Raposo G (2009) Exosomes-vesicular carriers for intercellular communication. Curr Opin Cell Biol 21(4): $575-581$

34. Dimov I, Jankovic Velickovic L, Stefanovic V (2009) Urinary exosomes. Sci World J 9:1107-1118

35. Cocucci E, Racchetti G, Meldolesi J (2009) Shedding microvesicles: artefacts no more. Trends Cell Biol 19(2):43-51

36. Chargaff E, West R (1946) The biological significance of the thromboplastic protein of blood. J Biol Chem 166(1):189-197

37. Wolf $P$ (1967) The nature and significance of platelet products in human plasma. Br J Haematol 13(3):269-288

38. Gyorgy B, Modos K, Pallinger E, Paloczi K, Pasztoi M, Misjak P, Deli MA, Sipos A, Szalai A, Voszka I, Polgar A, Toth K, Csete M, Nagy G, Gay S, Falus A, Kittel A, Buzas EI (2011) Detection and isolation of cell-derived microparticles are 
compromised by protein complexes due to shared biophysical parameters. Blood 117(4):e39-48

39. Yuana Y, Bertina RM, Osanto S (2010) Pre-analytical and analytical issues in the analysis of blood microparticles. Thromb Haemost 105 (3) (in press)

40. Smalley DM, Sheman NE, Nelson K, Theodorescu D (2008) Isolation and identification of potential urinary microparticle biomarkers of bladder cancer. J Proteome Res 7(5): 2088-2096

41. Baroni M, Pizzirani C, Pinotti M, Ferrari D, Adinolfi E, Calzavarini S, Caruso P, Bernardi F, Di Virgilio F (2007) Stimulation of P2 (P2X7) receptors in human dendritic cells induces the release of tissue factor-bearing microparticles. FASEB J 21(8): 1926-1933

42. Kahner BN, Dorsam RT, Kunapuli SP (2008) Role of P2Y receptor subtypes in platelet-derived microparticle generation. Front Biosci 13:433-439

43. Leroyer AS, Tedgui A, Boulanger CM (2008) Role of microparticles in atherothrombosis. J Intern Med 263(5):528-537

44. MacKenzie A, Wilson HL, Kiss-Toth E, Dower SK, North RA, Surprenant A (2001) Rapid secretion of interleukin-1beta by microvesicle shedding. Immunity 15(5):825-835

45. Boilard E, Nigrovic PA, Larabee K, Watts GF, Coblyn JS, Weinblatt ME, Massarotti EM, Remold-O'Donnell E, Farndale RW, Ware J, Lee DM (2010) Platelets amplify inflammation in arthritis via collagen-dependent microparticle production. Science 327(5965):580-583

46. Distler JH, Jungel A, Huber LC, Seemayer CA, Reich CF 3rd, Gay RE, Michel BA, Fontana A, Gay S, Pisetsky DS, Distler O (2005) The induction of matrix metalloproteinase and cytokine expression in synovial fibroblasts stimulated with immune cell microparticles. Proc Natl Acad Sci USA 102(8):2892-2897

47. Jungel A, Distler O, Schulze-Horsel U, Huber LC, Ha HR, Simmen B, Kalden JR, Pisetsky DS, Gay S, Distler JH (2007) Microparticles stimulate the synthesis of prostaglandin E(2) via induction of cyclooxygenase 2 and microsomal prostaglandin $\mathrm{E}$ synthase 1. Arthr Rheum 56(11):3564-3574

48. Giusti I, D'Ascenzo S, Millimaggi D, Taraboletti G, Carta G, Franceschini N, Pavan A, Dolo V (2008) Cathepsin B mediates the $\mathrm{pH}$-dependent proinvasive activity of tumor-shed microvesicles. Neoplasia 10(5):481-488

49. Antonyak MA, Li B, Boroughs LK, Johnson JL, Druso JE, Bryant KL, Holowka DA, Cerione RA (2011) Cancer cellderived microvesicles induce transformation by transferring tissue transglutaminase and fibronectin to recipient cells. Proc Natl Acad Sci USA 108(12):4852-4857

50. Pap E, Pallinger E, Falus A, Kiss AA, Kittel A, Kovacs P, Buzas EI (2008) T lymphocytes are targets for platelet- and trophoblastderived microvesicles during pregnancy. Placenta 29(9):826-832

51. Connor DE, Exner T, Ma DD, Joseph JE (2010) The majority of circulating platelet-derived microparticles fail to bind annexin $\mathrm{V}$, lack phospholipid-dependent procoagulant activity and demonstrate greater expression of glycoprotein Ib. Thromb Haemost 103(5):1044-1052

52. Sellam J, Proulle V, Jüngel A, Ittah M, Miceli Richard C, Gottenberg JE, Toti F, Benessiano J, Gay S, Freyssinet JM, Mariette X (2009) Increased levels of circulating microparticles in primary Sjögren's syndrome, systemic lupus erythematosus and rheumatoid arthritis and relation with disease activity. Arthritis Res Ther 11(5):R156

53. Leroyer AS, Anfosso F, Lacroix R, Sabatier F, Simoncini S, Njock SM, Jourde N, Brunet P, Camoin-Jau L, Sampol J, Dignat-George $F$ (2010) Endothelial-derived microparticles: Biological conveyors at the crossroad of inflammation, thrombosis and angiogenesis. Thromb Haemost 104(3):456-463
54. Aharon A, Brenner B (2009) Microparticles, thrombosis and cancer. Best Pract Res Clin Haematol 22(1):61-69

55. Piccin A, Murphy WG, Smith OP (2007) Circulating microparticles: pathophysiology and clinical implications. Blood Rev 21(3):157-171

56. Little KM, Smalley DM, Harthun NL, Ley K (2010) The plasma microparticle proteome. Semin Thromb Hemost 36(8):845-856

57. Amabile N, Rautou PE, Tedgui A, Boulanger CM (2010) Microparticles: key protagonists in cardiovascular disorders. Semin Thromb Hemost 36(8):907-916

58. Kerr JF, Wyllie AH, Currie AR (1972) Apoptosis: a basic biological phenomenon with wide-ranging implications in tissue kinetics. Br J Cancer 26(4):239-257

59. Sulston JE, Horvitz HR (1977) Post-embryonic cell lineages of the nematode, Caenorhabditis elegans. Dev Biol 56(1):110-156

60. Fixsen W, Sternberg P, Ellis H, Horvitz R (1985) Genes that affect cell fates during the development of Caenorhabditis elegans. Cold Spring Harb Symp Quant Biol 50:99-104

61. Hristov M, Erl W, Linder S, Weber PC (2004) Apoptotic bodies from endothelial cells enhance the number and initiate the differentiation of human endothelial progenitor cells in vitro. Blood 104(9):2761-2766

62. Beyer C, Pisetsky DS (2010) The role of microparticles in the pathogenesis of rheumatic diseases. Nat Rev Rheumatol 6(1):21-29

63. Bergsmedh A, Szeles A, Henriksson M, Bratt A, Folkman MJ, Spetz AL, Holmgren L (2001) Horizontal transfer of oncogenes by uptake of apoptotic bodies. Proc Natl Acad Sci USA 98(11):6407-6411

64. Holmgren L, Szeles A, Rajnavolgyi E, Folkman J, Klein G, Ernberg I, Falk KI (1999) Horizontal transfer of DNA by the uptake of apoptotic bodies. Blood 93(11):3956-3963

65. Bellone M, Iezzi G, Rovere P, Galati G, Ronchetti A, Protti MP, Davoust J, Rugarli C, Manfredi AA (1997) Processing of engulfed apoptotic bodies yields $\mathrm{T}$ cell epitopes. J Immunol 159(11):5391-5399

66. Cocca BA, Cline AM, Radic MZ (2002) Blebs and apoptotic bodies are B cell autoantigens. J Immunol 169(1):159-166

67. Savill J, Dransfield I, Gregory C, Haslett C (2002) A blast from the past: clearance of apoptotic cells regulates immune responses. Nat Rev Immunol 2(12):965-975

68. Dignat-George F, Freyssinet JM, Key NS (2009) Centrifugation is a crucial step impacting microparticle measurement. Platelets 20 (3):225-226; author reply 227-228

69. Chen C, Skog J, Hsu CH, Lessard RT, Balaj L, Wurdinger T, Carter BS, Breakefield XO, Toner M, Irimia D (2010) Microfluidic isolation and transcriptome analysis of serum microvesicles. Lab Chip 10(4):505-511

70. Booth AM, Fang Y, Fallon JK, Yang JM, Hildreth JE, Gould SJ (2006) Exosomes and HIV Gag bud from endosome-like domains of the $\mathrm{T}$ cell plasma membrane. $\mathrm{J}$ Cell Biol 172(6):923-935

71. Rubin O, Crettaz D, Tissot JD, Lion N (2010) Pre-analytical and methodological challenges in red blood cell microparticle proteomics. Talanta 82(1):1-8

72. Lawrie AS, Albanyan A, Cardigan RA, Mackie IJ, Harrison P (2009) Microparticle sizing by dynamic light scattering in freshfrozen plasma. Vox Sang 96(3):206-212

73. Yuana Y, Oosterkamp TH, Bahatyrova S, Ashcroft B, Garcia Rodriguez P, Bertina RM, Osanto S (2010) Atomic force microscopy: a novel approach to the detection of nanosized blood microparticles. J Thromb Haemost 8(2):315-323

74. Miyazaki Y, Nomura S, Miyake T, Kagawa H, Kitada C, Taniguchi H, Komiyama Y, Fujimura Y, Ikeda Y, Fukuhara S (1996) High shear stress can initiate both platelet aggregation 
and shedding of procoagulant containing microparticles. Blood 88(9):3456-3464

75. Bode AP, Orton SM, Frye MJ, Udis BJ (1991) Vesiculation of platelets during in vitro aging. Blood 77(4):887-895

76. Dey-Hazra E, Hertel B, Kirsch T, Woywodt A, Lovric S, Haller H, Haubitz M, Erdbruegger U (2010) Detection of circulating microparticles by flow cytometry: influence of centrifugation, filtration of buffer, and freezing. Vasc Health Risk Manag 6:1125-1133

77. Fernández-Llama P, Khositseth S, Gonzales PA, Star RA, Pisitkun T, Knepper MA (2010) Tamm-Horsfall protein and urinary exosome isolation. Kidney Int Apr 77(8):736-742

78. Cantin R, Diou J, Belanger D, Tremblay AM, Gilbert C (2008) Discrimination between exosomes and HIV-1: purification of both vesicles from cell-free supernatants. J Immunol Methods 338(1-2):21-30

79. Robert S, Poncelet P, Lacroix R, Arnaud L, Giraudo L, Hauchard A, Sampol J, Dignat-George F (2009) Standardization of platelet-derived microparticle counting using calibrated beads and a Cytomics FC500 routine flow cytometer: a first step towards multicenter studies? J Thromb Haemost 7(1):190-197

80. Lacroix R, Robert S, Poncelet P, Kasthuri RS, Key NS, DignatGeorge F (2010) Standardization of platelet-derived microparticle enumeration by flow cytometry using calibrated beads: results of ISTH SSC collaborative workshop. J Thromb Haemost. doi:10.1111/j.1538-7836.2010.04047.x

81. Cerri C, Chimenti D, Conti I, Neri T, Paggiaro P, Celi A (2006) Monocyte/macrophage-derived microparticles up-regulate inflammatory mediator synthesis by human airway epithelial cells. J Immunol 177(3):1975-1980

82. Enjeti AK, Lincz L, Seldon M (2008) Bio-maleimide as a generic stain for detection and quantitation of microparticles. Int J Lab Hematol 30(3):196-199

83. Flaumenhaft R, Dilks JR, Richardson J, Alden E, Patel-Hett SR, Battinelli E, Klement GL, Sola-Visner M, Italiano JE, Jr. (2009) Megakaryocyte-derived microparticles: direct visualization and distinction from platelet-derived microparticles. Blood 113(5):1112-1121. doi:10.1182/blood-2008-06-163832

84. Rood IM, Deegens JK, Merchant ML, Tamboer WP, Wilkey DW, Wetzels JF, Klein JB (2010) Comparison of three methods for isolation of urinary microvesicles to identify biomarkers of nephrotic syndrome. Kidney Int 78(8):810-816

85. Krishnamoorthy L, Bess JW Jr, Preston AB, Nagashima K, Mahal LK (2009) HIV-1 and microvesicles from T cells share a common glycome, arguing for a common origin. Nat Chem Biol 5(4):244-250

86. Park IW, He JJ (2010) HIV-1 is budded from CD4+ T lymphocytes independently of exosomes. Virol J 7:234

87. Walker JD, Maier CL, Pober JS (2009) Cytomegalovirusinfected human endothelial cells can stimulate allogeneic CD4+ memory $\mathrm{T}$ cells by releasing antigenic exosomes. J Immunol 182(3):1548-1559

88. Meckes DG Jr, Shair KH, Marquitz AR, Kung CP, Edwards RH, Raab-Traub N (2010) Human tumor virus utilizes exosomes for intercellular communication. Proc Natl Acad Sci USA 107(47): 20370-20375

89. Qu Y, Ramachandra L, Mohr S, Franchi L, Harding CV, Nunez G, Dubyak GR (2009) P2X7 receptor-stimulated secretion of MHC class II-containing exosomes requires the ASC/NLRP3 inflammasome but is independent of caspase-1. J Immunol 182(8):5052-5062

90. Constantinescu P, Wang B, Kovacevic K, Jalilian I, Bosman GJ, Wiley JS, Sluyter R (2010) P2X7 receptor activation induces cell death and microparticle release in murine erythroleukemia cells. Biochim Biophys Acta 1798(9):1797-1804
91. Heijnen HF, Schiel AE, Fijnheer R, Geuze HJ, Sixma JJ (1999) Activated platelets release two types of membrane vesicles: microvesicles by surface shedding and exosomes derived from exocytosis of multivesicular bodies and alpha-granules. Blood 94(11):3791-3799

92. Wewers MD, Sarkar A (2009) P2X(7) receptor and macrophage function. Purinergic Signal 5(2):189-195

93. Shemon AN, Sluyter R, Wiley JS (2007) Rottlerin inhibits $\mathrm{P} 2 \mathrm{X}(7)$ receptor-stimulated phospholipase D activity in chronic lymphocytic leukaemia B-lymphocytes. Immunol Cell Biol 85(1):68-72

94. Shemon AN, Sluyter R, Stokes L, Manley PW, Wiley JS (2008) Inhibition of the human $\mathrm{P} 2 \mathrm{X} 7$ receptor by a novel protein tyrosine kinase antagonist. Biochem Biophys Res Commun 365(3):515-520

95. Théry C, Regnault A, Garin J, Wolfers J, Zitvogel L, RicciardiCastagnoli P, Raposo G, Amigorena S (1999) Molecular characterization of dendritic cell-derived exosomes. Selective accumulation of the heat shock protein hsc73. J Cell Biol 147(3):599-610

96. Alonso R, Rodríguez MC, Pindado J, Merino E, Mérida I, Izquierdo M (2005) Diacylglycerol kinase alpha regulates the secretion of lethal exosomes bearing Fas ligand during activation-induced cell death of $\mathrm{T}$ lymphocytes. J Biol Chem 280(31):28439-28450

97. Pasquet JM, Dachary-Prigent J, Nurden AT (1998) Microvesicle release is associated with extensive protein tyrosine dephosphorylation in platelets stimulated by A23187 or a mixture of thrombin and collagen. Biochem J 333(Pt 3):591-599

98. Henriksson CE, Klingenberg O, Hellum M, Landsverk KS, Joo GB, Westvik AB, Kierulf P (2007) Calcium ionophore-induced de-encryption of tissue factor in monocytes is associated with extensive cell death. Thromb Res 119(5):621-630

99. Crespin M, Vidal C, Picard F, Lacombe C, Fontenay M (2009) Activation of PAK1/2 during the shedding of platelet microvesicles. Blood Coagul Fibrinolysis 20(1):63-70

100. Parolini I, Federici C, Raggi C, Lugini L, Palleschi S, De Milito A, Coscia C, Iessi E, Logozzi M, Molinari A, Colone M, Tatti M, Sargiacomo M, Fais S (2009) Microenvironmental pH is a key factor for exosome traffic in tumor cells. J Biol Chem 284(49):34211-34222

101. Muralidharan-Chari V, Clancy J, Plou C, Romao M, Chavrier P, Raposo G, D'Souza-Schorey C (2009) ARF6-regulated shedding of tumor cell-derived plasma membrane microvesicles. Curr Biol 19(22):1875-1885

102. Trajkovic K, Hsu C, Chiantia S, Rajendran L, Wenzel D, Wieland F, Schwille P, Brugger B, Simons M (2008) Ceramide triggers budding of exosome vesicles into multivesicular endosomes. Science 319(5867):1244-1247

103. Gonzalez LJ, Gibbons E, Bailey RW, Fairbourn J, Nguyen T, Smith SK, Best KB, Nelson J, Judd AM, Bell JD (2009) The influence of membrane physical properties on microvesicle release in human erythrocytes. PMC Biophys 2(1):7

104. Fong KP, Barry C, Tran AN, Traxler EA, Wannemacher KM, Tang HY, Speicher KD, Blair IA, Speicher DW, Grosser T, Brass LF (2010) Deciphering the human platelet sheddome. Blood 117(1):e15-e26

105. Ostrowski M, Carmo NB, Krumeich S, Fanget I, Raposo G, Savina A, Moita CF, Schauer K, Hume AN, Freitas RP, Goud B, Benaroch P, Hacohen N, Fukuda M, Desnos C, Seabra MC, Darchen F, Amigorena S, Moita LF, Thery C (2010) Rab27a and Rab27b control different steps of the exosome secretion pathway. Nat Cell Biol 12(1):19-30; sup pp 1-13

106. Castaman G, Yu-Feng L, Battistin E, Rodeghiero F (1997) Characterization of a novel bleeding disorder with isolated 
prolonged bleeding time and deficiency of platelet microvesicle generation. Br J Haematol 96(3):458-463

107. Brooks MB, Catalfamo JL, Brown HA, Ivanova P, Lovaglio J (2002) A hereditary bleeding disorder of dogs caused by a lack of platelet procoagulant activity. Blood 99(7):2434-2441

108. Brooks M, Etter K, Catalfamo J, Brisbin A, Bustamante C, Mezey J (2010) A genome-wide linkage scan in German shepherd dogs localizes canine platelet procoagulant deficiency (Scott syndrome) to canine chromosome 27. Gene 450(1-2): $70-75$

109. Ward JR, West PW, Ariaans MP, Parker LC, Francis SE, Crossman DC, Sabroe I, Wilson HL (2010) Temporal interleukin-1beta secretion from primary human peripheral blood monocytes by P2X7-independent and P2X7-dependent mechanisms. J Biol Chem 285(30):23147-23158

110. Stokes L, Fuller SJ, Sluyter R, Skarratt KK, Gu BJ, Wiley JS (2010) Two haplotypes of the P2X(7) receptor containing the Ala-348 to Thr polymorphism exhibit a gain-of-function effect and enhanced interleukin-1beta secretion. FASEB J 24(8): 2916-2927

111. Sluyter R, Shemon AN, Wiley JS (2004) Glu496 to Ala polymorphism in the P2X7 receptor impairs ATP-induced IL-1 beta release from human monocytes. J Immunol 172(6): 3399-3405

112. Labasi JM, Petrushova N, Donovan C, McCurdy S, Lira P, Payette MM, Brissette W, Wicks JR, Audoly L, Gabel CA (2002) Absence of the P2X7 receptor alters leukocyte function and attenuates an inflammatory response. J Immunol 168(12): 6436-6445

113. Lespagnol A, Duflaut D, Beekman C, Blanc L, Fiucci G, Marine JC, Vidal M, Amson R, Telerman A (2008) Exosome secretion, including the DNA damage-induced p53-dependent secretory pathway, is severely compromised in TSAP6/Steap3-null mice. Cell Death Differ 15(11):1723-1733

114. Li MO, Sarkisian MR, Mehal WZ, Rakic P, Flavell RA (2003) Phosphatidylserine receptor is required for clearance of apoptotic cells. Science 302(5650):1560-1563

115. Rodriguez-Manzanet R, Sanjuan MA, Wu HY, Quintana FJ, Xiao S, Anderson AC, Weiner HL, Green DR, Kuchroo VK (2010) T and B cell hyperactivity and autoimmunity associated with niche-specific defects in apoptotic body clearance in TIM4-deficient mice. Proc Natl Acad Sci USA 107(19):8706-8711

116. Lemke G, Rothlin CV (2008) Immunobiology of the TAM receptors. Nat Rev Immunol 8(5):327-336

117. Lu Q, Lemke G (2001) Homeostatic regulation of the immune system by receptor tyrosine kinases of the Tyro 3 family. Science 293(5528):306-311

118. Andrade F, Casciola-Rosen L, Rosen A (2000) Apoptosis in systemic lupus erythematosus. Clinical implications. Rheum Dis Clin North Am 26(2):215-227

119. Munoz LE, van Bavel C, Franz S, Berden J, Herrmann M, van der Vlag J (2008) Apoptosis in the pathogenesis of systemic lupus erythematosus. Lupus 17(5):371-375

120. Kamradt T, Mitchison NA (2001) Tolerance and autoimmunity. N Engl J Med 344(9):655-664

121. Green DR (2003) Overview: apoptotic signaling pathways in the immune system. Immunol Rev 193:5-9

122. Ren Y, Tang J, Mok MY, Chan AW, Wu A, Lau CS (2003) Increased apoptotic neutrophils and macrophages and impaired macrophage phagocytic clearance of apoptotic neutrophils in systemic lupus erythematosus. Arthr Rheum 48(10):2888-2897

123. Shoshan Y, Shapira I, Toubi E, Frolkis I, Yaron M, Mevorach D (2001) Accelerated Fas-mediated apoptosis of monocytes and maturing macrophages from patients with systemic lupus erythematosus: relevance to in vitro impairment of interaction with iC3b-opsonized apoptotic cells. J Immunol 167(10):5963-5969
124. Subra C, Laulagnier K, Perret B, Record M (2007) Exosome lipidomics unravels lipid sorting at the level of multivesicular bodies. Biochimie 89(2):205-212

125. Vidal M, Sainte-Marie J, Philippot JR, Bienvenue A (1989) Asymmetric distribution of phospholipids in the membrane of vesicles released during in vitro maturation of guinea pig reticulocytes: evidence precluding a role for "aminophospholipid translocase". J Cell Physiol 140(3):455-462

126. Wubbolts R, Leckie RS, Veenhuizen PT, Schwarzmann G, Mobius W, Hoernschemeyer J, Slot JW, Geuze HJ, Stoorvogel W (2003) Proteomic and biochemical analyses of human B cellderived exosomes. Potential implications for their function and multivesicular body formation. J Biol Chem 278(13): 10963-10972

127. Laulagnier K, Motta C, Hamdi S, Roy S, Fauvelle F, Pageaux JF, Kobayashi T, Salles JP, Perret B, Bonnerot C, Record M (2004) Mast cell- and dendritic cell-derived exosomes display a specific lipid composition and an unusual membrane organization. Biochem J 380(Pt 1):161-171

128. Mayr M, Grainger D, Mayr U, Leroyer AS, Leseche G, Sidibe A, Herbin O, Yin X, Gomes A, Madhu B, Griffiths JR, Xu Q, Tedgui A, Boulanger CM (2009) Proteomics, metabolomics, and immunomics on microparticles derived from human atherosclerotic plaques. Circ Cardiovasc Genet 2(4):379-388

129. Mathivanan S, Simpson RJ (2009) ExoCarta: a compendium of exosomal proteins and RNA. Proteomics 9(21):4997-5000

130. Looze C, Yui D, Leung L, Ingham M, Kaler M, Yao X, Wu WW, Shen RF, Daniels MP, Levine SJ (2009) Proteomic profiling of human plasma exosomes identifies PPARgamma as an exosome-associated protein. Biochem Biophys Res Commun 378(3):433-438

131. Admyre C, Johansson SM, Qazi KR, Filen JJ, Lahesmaa R, Norman M, Neve EP, Scheynius A, Gabrielsson S (2007) Exosomes with immune modulatory features are present in human breast milk. J Immunol 179(3):1969-1978

132. Graner MW, Alzate O, Dechkovskaia AM, Keene JD, Sampson JH, Mitchell DA, Bigner DD (2009) Proteomic and immunologic analyses of brain tumor exosomes. FASEB J 23(5):1541-1557

133. Bard MP, Hegmans JP, Hemmes A, Luider TM, Willemsen R, Severijnen LA, van Meerbeeck JP, Burgers SA, Hoogsteden HC, Lambrecht BN (2004) Proteomic analysis of exosomes isolated from human malignant pleural effusions. Am J Respir Cell Mol Biol 31(1):114-121

134. Prokopi M, Pula G, Mayr U, Devue C, Gallagher J, Xiao Q, Boulanger CM, Westwood N, Urbich C, Willeit J, Steiner M, Breuss J, Xu Q, Kiechl S, Mayr M (2009) Proteomic analysis reveals presence of platelet microparticles in endothelial progenitor cell cultures. Blood 114(3):723-732

135. Smalley DM, Root KE, Cho H, Ross MM, Ley K (2007) Proteomic discovery of 21 proteins expressed in human plasmaderived but not platelet-derived microparticles. Thromb Haemost 97(1):67-80

136. Dean WL, Lee MJ, Cummins TD, Schultz DJ, Powell DW (2009) Proteomic and functional characterisation of platelet microparticle size classes. Thromb Haemost 102(4):711-718

137. O’Donovan C, Martin MJ, Gattiker A, Gasteiger E, Bairoch A, Apweiler R (2002) High-quality protein knowledge resource: SWISS-PROT and TrEMBL. Brief Bioinform 3(3): 275-284

138. O'Donovan C, Apweiler R (2011) A guide to UniProt for protein scientists. Methods Mol Biol 694:25-35

139. Eder C (2009) Mechanisms of interleukin-1beta release. Immunobiology 214(7):543-553

140. Bendtsen JD, Jensen LJ, Blom N, Von Heijne G, Brunak S (2004) Feature-based prediction of non-classical and leaderless protein secretion. Protein Eng Des Sel 17(4):349-356 
141. http://www.cbs.dtu.dk/services/SecretomeP

142. Lowry SF, Lin E, Calvano SE (2008) Chapter 4: Mediators of Inflammation and injury. In: Norton JA, Barie PS, Bollinger RR et al (eds) Surgery: basic science and clinical evidence, 2nd edn. Springer, London, p 85

143. Qu Y, Franchi L, Nunez G, Dubyak GR (2007) Nonclassical IL-1 beta secretion stimulated by P2X7 receptors is dependent on inflammasome activation and correlated with exosome release in murine macrophages. J Immunol 179(3): 1913-1925

144. Mohan SK, Rani SG, Yu C (2010) The heterohexameric complex structure, a component in the non-classical pathway for fibroblast growth factor 1 (FGF1) secretion. J Biol Chem 285(20):15464-15475

145. Izquierdo-Useros N, Naranjo-Gomez M, Erkizia I, Puertas MC, Borras FE, Blanco J, Martinez-Picado J (2010) HIV and mature dendritic cells: Trojan exosomes riding the Trojan horse? PLoS Pathog 6(3):e1000740

146. Lui WY, Lee WM, Cheng CY (2003) Sertoli-germ cell adherens junction dynamics in the testis are regulated by RhoB GTPase via the ROCK/LIMK signaling pathway. Biol Reprod 68(6) :2189-2206

147. Werner N, Wassmann S, Ahlers P, Kosiol S, Nickenig G (2006) Circulating CD31+/annexin V+ apoptotic microparticles correlate with coronary endothelial function in patients with coronary artery disease. Arterioscler Thromb Vasc Biol 26(1): $112-116$

148. Esposito K, Ciotola M, Schisano B, Gualdiero R, Sardelli L, Misso L, Giannetti G, Giugliano D (2006) Endothelial microparticles correlate with endothelial dysfunction in obese women. J Clin Endocrinol Metab 91(9):3676-3679

149. Amabile N, Guerin AP, Leroyer A, Mallat Z, Nguyen C, Boddaert J, London GM, Tedgui A, Boulanger CM (2005) Circulating endothelial microparticles are associated with vascular dysfunction in patients with end-stage renal failure. J Am Soc Nephrol 16(11):3381-3388

150. Mallat Z, Benamer H, Hugel B, Benessiano J, Steg PG, Freyssinet JM, Tedgui A (2000) Elevated levels of shed membrane microparticles with procoagulant potential in the peripheral circulating blood of patients with acute coronary syndromes. Circulation 101(8):841-843

151. Preston RA, Jy W, Jimenez JJ, Mauro LM, Horstman LL, Valle M, Aime G, Ahn YS (2003) Effects of severe hypertension on endothelial and platelet microparticles. Hypertension 41(2): 211-217

152. Amabile N, Heiss C, Real WM, Minasi P, McGlothlin D, Rame EJ, Grossman W, De Marco T, Yeghiazarians Y (2008) Circulating endothelial microparticle levels predict hemodynamic severity of pulmonary hypertension. Am J Respir Crit Care Med 177(11):1268-1275

153. Chironi GN, Boulanger CM, Simon A, Dignat-George F, Freyssinet JM, Tedgui A (2009) Endothelial microparticles in diseases. Cell Tissue Res 335(1):143-151

154. Brodsky SV, Zhang F, Nasjletti A, Goligorsky MS (2004) Endothelium-derived microparticles impair endothelial function in vitro. Am J Physiol Heart Circ Physiol 286(5):H1910-H1915

155. Li X, Cong H (2009) Platelet-derived microparticles and the potential of glycoprotein IIb/IIIa antagonists in treating acute coronary syndrome. Tex Heart Inst J 36(2):134-139

156. Salanova B, Choi M, Rolle S, Wellner M, Luft FC, Kettritz R (2007) Beta2-integrins and acquired glycoprotein IIb/IIIa (GPIIb/IIIa) receptors cooperate in NF-kappaB activation of human neutrophils. J Biol Chem 282(38):27960-27969

157. Iero M, Valenti R, Huber V, Filipazzi P, Parmiani G, Fais S, Rivoltini L (2008) Tumour-released exosomes and their implications in cancer immunity. Cell Death Differ 15(1):80-88
158. Muralidharan-Chari V, Clancy JW, Sedgwick A, D'SouzaSchorey C (2010) Microvesicles: mediators of extracellular communication during cancer progression. J Cell Sci $123(\mathrm{Pt}$ 10):1603-1611

159. Skog J, Wurdinger T, van Rijn S, Meijer DH, Gainche L, SenaEsteves M, Curry WT Jr, Carter BS, Krichevsky AM, Breakefield XO (2008) Glioblastoma microvesicles transport RNA and proteins that promote tumour growth and provide diagnostic biomarkers. Nat Cell Biol 10(12):1470-1476

160. Kosaka N, Iguchi H, Ochiya T (2010) Circulating microRNA in body fluid: a new potential biomarker for cancer diagnosis and prognosis. Cancer Sci 101(10):2087-2092

161. Taylor DD, Gercel-Taylor C (2008) MicroRNA signatures of tumor-derived exosomes as diagnostic biomarkers of ovarian cancer. Gynecol Oncol 110(1):13-21

162. El-Hefnawy T, Raja S, Kelly L, Bigbee WL, Kirkwood JM, Luketich JD, Godfrey TE (2004) Characterization of amplifiable, circulating RNA in plasma and its potential as a tool for cancer diagnostics. Clin Chem 50(3):564-573

163. Rabinowits G, Gercel-Taylor C, Day JM, Taylor DD, Kloecker GH (2009) Exosomal microRNA: a diagnostic marker for lung cancer. Clin Lung Cancer 10(1):42-46

164. Kuslich C, Pawlowski T, Kimbrough J, Deng T, Tinder T, Kim J, Spetzler D (2010) Plasma exosomes are a robust biosignature for prostate cancer. In: Paper presented at the American Academy of Cancer Research, Washington D.C

165. Spetzler D, Pawlowski T, Kimbrough J, Deng T, Tinder T, Kim J, Kuslich C (2010) Plasma exosome-based biosignatures: a novel method for early diagnosis of colorectal cancer

166. Spetzler D, Tinder T, Kankipati S, Maheshwari M, Kuslich CD (2011) A circulating microvesicle-based biosignature for the detection of colorectal cancer. J Clin Oncol 29: suppl 4; abstr 373

167. Alvarez-Erviti L, Seow Y, Yin H, Betts C, Lakhal S, Wood MJ (2011) Delivery of siRNA to the mouse brain by systemic injection of targeted exosomes. Nat Biotechnol

168. Pereira J, Alfaro G, Goycoolea M, Quiroga T, Ocqueteau M, Massardo L, Perez C, Saez C, Panes O, Matus V, Mezzano D (2006) Circulating platelet-derived microparticles in systemic lupus erythematosus. Association with increased thrombin generation and procoagulant state. Thromb Haemost 95(1):94-99

169. Dignat-George F, Camoin-Jau L, Sabatier F, Arnoux D, Anfosso F, Bardin N, Veit V, Combes V, Gentile S, Moal V, Sanmarco M, Sampol J (2004) Endothelial microparticles: a potential contribution to the thrombotic complications of the antiphospholipid syndrome. Thromb Haemost 91(4):667-673

170. Jy W, Tiede M, Bidot CJ, Horstman LL, Jimenez JJ, Chirinos J, Ahn YS (2007) Platelet activation rather than endothelial injury identifies risk of thrombosis in subjects positive for antiphospholipid antibodies. Thromb Res 121(3):319-325

171. Knijff-Dutmer EA, Koerts J, Nieuwland R, Kalsbeek-Batenburg EM, van de Laar MA (2002) Elevated levels of platelet microparticles are associated with disease activity in rheumatoid arthritis. Arthritis Rheum 46(6):1498-1503

172. Messer L, Alsaleh G, Freyssinet JM, Zobairi F, Leray I, Gottenberg JE, Sibilia J, Toti-Orfanoudakis F, Wachsmann D (2009) Microparticle-induced release of B-lymphocyte regulators by rheumatoid synoviocytes. Arthritis Res Ther 11(2):R40

173. Nomura S, Inami N, Ozaki Y, Kagawa H, Fukuhara S (2008) Significance of microparticles in progressive systemic sclerosis with interstitial pneumonia. Platelets 19(3):192-198

174. Guiducci S, Distler JH, Jungel A, Huscher D, Huber LC, Michel BA, Gay RE, Pisetsky DS, Gay S, Matucci-Cerinic M, Distler O (2008) The relationship between plasma microparticles and disease manifestations in patients with systemic sclerosis. Arthritis Rheum 58(9):2845-2853 
175. Brogan PA, Dillon MJ (2004) Endothelial microparticles and the diagnosis of the vasculitides. Intern Med 43(12):1115-1119

176. Daniel L, Fakhouri F, Joly D, Mouthon L, Nusbaum P, Grunfeld JP, Schifferli J, Guillevin L, Lesavre P, Halbwachs-Mecarelli L (2006) Increase of circulating neutrophil and platelet microparticles during acute vasculitis and hemodialysis. Kidney Int 69(8):1416-1423

177. Erdbruegger U, Grossheim M, Hertel B, Wyss K, Kirsch T, Woywodt A, Haller H, Haubitz M (2008) Diagnostic role of endothelial microparticles in vasculitis. Rheumatology (Oxford) 47(12):1820-1825

178. Sabatier F, Darmon P, Hugel B, Combes V, Sanmarco M, Velut JG, Arnoux D, Charpiot P, Freyssinet JM, Oliver C, Sampol J, Dignat-George F (2002) Type 1 and type 2 diabetic patients display different patterns of cellular microparticles. Diabetes 51(9):2840-2845

179. Sheremata WA, Jy W, Horstman LL, Ahn YS, Alexander JS, Minagar A (2008) Evidence of platelet activation in multiple sclerosis. J Neuroinflamm 5:27

180. Minagar A, Jy W, Jimenez JJ, Sheremata WA, Mauro LM, Mao WW, Horstman LL, Ahn YS (2001) Elevated plasma endothelial microparticles in multiple sclerosis. Neurology 56(10): 1319-1324

181. Bernard S, Loffroy R, Serusclat A, Boussel L, Bonnefoy E, Thevenon C, Rabilloud M, Revel D, Moulin P, Douek P (2009) Increased levels of endothelial microparticles CD144 (VECadherin) positives in type 2 diabetic patients with coronary noncalcified plaques evaluated by multidetector computed tomography (MDCT). Atherosclerosis 203(2):429-435

182. Nomura S, Uehata S, Saito S, Osumi K, Ozeki Y, Kimura Y (2003) Enzyme immunoassay detection of platelet-derived microparticles and RANTES in acute coronary syndrome. Thromb Haemost 89(3):506-512

183. Bernal-Mizrachi L, Jy W, Jimenez JJ, Pastor J, Mauro LM, Horstman LL, de Marchena E, Ahn YS (2003) High levels of circulating endothelial microparticles in patients with acute coronary syndromes. Am Heart J 145(6):962-970

184. Bernal-Mizrachi L, Jy W, Fierro C, Macdonough R, Velazques HA, Purow J, Jimenez JJ, Horstman LL, Ferreira A, de Marchena E, Ahn YS (2004) Endothelial microparticles correlate with high-risk angiographic lesions in acute coronary syndromes. Int J Cardiol 97(3):439-446

185. Nozaki T, Sugiyama S, Koga H, Sugamura K, Ohba K, Matsuzawa Y, Sumida H, Matsui K, Jinnouchi H, Ogawa H (2009) Significance of a multiple biomarkers strategy including endothelial dysfunction to improve risk stratification for cardiovascular events in patients at high risk for coronary heart disease. J Am Coll Cardiol 54(7):601-608

186. Huang PH, Huang SS, Chen YH, Lin CP, Chiang KH, Chen JS, Tsai HY, Lin FY, Chen JW, Lin SJ (2010) Increased circulating $\mathrm{CD} 31+$ /annexin $\mathrm{V}+$ apoptotic microparticles and decreased circulating endothelial progenitor cell levels in hypertensive patients with microalbuminuria. J Hypertens 28(8):1655-1665

187. Diehl P, Aleker M, Helbing T, Sossong V, Germann M, Sorichter S, Bode C, Moser M (2010) Increased platelet, leukocyte and endothelial microparticles predict enhanced coagulation and vascular inflammation in pulmonary hypertension. $\mathrm{J}$ Thromb Thrombolysis (in press)

188. Bakouboula B, Morel O, Faure A, Zobairi F, Jesel L, Trinh A, Zupan M, Canuet M, Grunebaum L, Brunette A, Desprez D, Chabot F, Weitzenblum E, Freyssinet JM, Chaouat A, Toti F (2008) Procoagulant membrane microparticles correlate with the severity of pulmonary arterial hypertension. Am J Respir Crit Care Med 177(5):536-543

189. Rossig L, Haendeler J, Mallat Z, Hugel B, Freyssinet JM, Tedgui A, Dimmeler S, Zeiher AM (2000) Congestive heart failure induces endothelial cell apoptosis: protective role of carvedilol. J Am Coll Cardiol 36(7):2081-2089

190. Nozaki T, Sugiyama S, Sugamura K, Ohba K, Matsuzawa Y, Konishi M, Matsubara J, Akiyama E, Sumida H, Matsui K, Jinnouchi H, Ogawa H (2010) Prognostic value of endothelial microparticles in patients with heart failure. Eur $\mathrm{J}$ Heart Fail 12(11):1223-1228

191. Garcia S, Chirinos J, Jimenez J, Del Carpio Munoz F, Canoniero M, Jy W, Horstman L, Ahn Y (2005) Phenotypic assessment of endothelial microparticles in patients with heart failure and after heart transplantation: switch from cell activation to apoptosis. J Heart Lung Transplant 24(12):2184-2189

192. Chirinos JA, Heresi GA, Velasquez H, Jy W, Jimenez JJ, Ahn E, Horstman LL, Soriano AO, Zambrano JP, Ahn YS (2005) Elevation of endothelial microparticles, platelets, and leukocyte activation in patients with venous thromboembolism. J Am Coll Cardiol 45(9):1467-1471

193. Rectenwald JE, Myers DD Jr, Hawley AE, Longo C, Henke PK, Guire KE, Schmaier AH, Wakefield TW (2005) D-dimer, P-selectin, and microparticles: novel markers to predict deep venous thrombosis. A pilot study. Thromb Haemost 94(6): 1312-1317

194. Bal L, Ederhy S, Di Angelantonio E, Toti F, Zobairi F, Dufaitre G, Meuleman C, Mallat Z, Boccara F, Tedgui A, Freyssinet JM, Cohen A (2010) Circulating procoagulant microparticles in acute pulmonary embolism: a case-control study. Int J Cardiol 145(2):321-322

195. Darnige L, Helley D, Fischer AM, Emmerich J, Smadja DM, Fiessinger JN (2010) Platelet microparticle levels: a biomarker of thromboangiitis obliterans (Buerger's disease) exacerbation. J Cell Mol Med 14(1-2):449-451

196. Chironi G, Simon A, Hugel B, Del Pino M, Gariepy J, Freyssinet JM, Tedgui A (2006) Circulating leukocyte-derived microparticles predict subclinical atherosclerosis burden in asymptomatic subjects. Arterioscler Thromb Vasc Biol 26(12): 2775-2780

197. Michelsen AE, Noto AT, Brodin E, Mathiesen EB, Brosstad F, Hansen JB (2009) Elevated levels of platelet microparticles in carotid atherosclerosis and during the postprandial state. Thromb Res 123(6):881-886

198. Lee YJ, Jy W, Horstman LL, Janania J, Reyes Y, Kelley RE, Ahn YS (1993) Elevated platelet microparticles in transient ischemic attacks, lacunar infarcts, and multiinfarct dementias. Thromb Res 72(4):295-304

199. Lackner P, Dietmann A, Beer R, Fischer M, Broessner G, Helbok R, Marxgut J, Pfausler B, Schmutzhard E (2010) Cellular microparticles as a marker for cerebral vasospasm in spontaneous subarachnoid hemorrhage. Stroke 41(10):2353-2357

200. Lukasik M, Rozalski M, Luzak B, Michalak S, Kozubski W, Watala C (2010) Platelet activation and reactivity in the convalescent phase of ischaemic stroke. Thromb Haemost 103(3): 644-650

201. Jung KH, Chu K, Lee ST, Park HK, Bahn JJ, Kim DH, Kim JH, Kim M, Kun Lee S, Roh JK (2009) Circulating endothelial microparticles as a marker of cerebrovascular disease. Ann Neurol 66(2):191-199, 186

202. Simak J, Gelderman MP, Yu H, Wright V, Baird AE (2006) Circulating endothelial microparticles in acute ischemic stroke: a link to severity, lesion volume and outcome. J Thromb Haemost 4(6):1296-1302

203. Simak J, Holada K, Risitano AM, Zivny JH, Young NS, Vostal JG (2004) Elevated circulating endothelial membrane microparticles in paroxysmal nocturnal haemoglobinuria. $\mathrm{Br} \mathrm{J}$ Haematol 125(6):804-813

204. Shet AS, Aras O, Gupta K, Hass MJ, Rausch DJ, Saba N, Koopmeiners L, Key NS, Hebbel RP (2003) Sickle blood contains 
tissue factor-positive microparticles derived from endothelial cells and monocytes. Blood 102(7):2678-2683

205. Tantawy AA, Matter RM, Hamed AA, Shams El Din El Telbany MA (2010) Platelet microparticles in immune thrombocytopenic purpura in pediatrics. Pediatr Hematol Oncol 27(4):283-296

206. Jimenez JJ, Jy W, Mauro LM, Horstman LL, Soderland C, Ahn YS (2003) Endothelial microparticles released in thrombotic thrombocytopenic purpura express von Willebrand factor and markers of endothelial activation. $\mathrm{Br} \mathrm{J}$ Haematol 123(5): 896-902

207. Mitchell PJ, Welton J, Staffurth J, Court J, Mason MD, Tabi Z, Clayton A (2009) Can urinary exosomes act as treatment response markers in prostate cancer? J Transl Med 7:4

208. Nilsson J, Skog J, Nordstrand A, Baranov V, Mincheva-Nilsson L, Breakefield XO, Widmark A (2009) Prostate cancer-derived urine exosomes: a novel approach to biomarkers for prostate cancer. Br J Cancer 100(10):1603-1607

209. Kim HK, Song KS, Park YS, Kang YH, Lee YJ, Lee KR, Ryu KW, Bae JM, Kim S (2003) Elevated levels of circulating platelet microparticles, VEGF, IL-6 and RANTES in patients with gastric cancer: possible role of a metastasis predictor. Eur $\mathbf{J}$ Cancer 39(2):184-191

210. Logozzi M, De Milito A, Lugini L, Borghi M, Calabro L, Spada M, Perdicchio M, Marino ML, Federici C, Iessi E, Brambilla D, Venturi G, Lozupone F, Santinami M, Huber V, Maio M, Rivoltini L, Fais S (2009) High levels of exosomes expressing CD63 and caveolin-1 in plasma of melanoma patients. PLoS One 4(4):e5219

211. Kim JW, Wieckowski E, Taylor DD, Reichert TE, Watkins S, Whiteside TL (2005) Fas ligand-positive membranous vesicles isolated from sera of patients with oral cancer induce apoptosis of activated T lymphocytes. Clin Cancer Res 11(3):1010-1020

212. Hron G, Kollars M, Weber H, Sagaster V, Quehenberger P, Eichinger S, Kyrle PA, Weltermann A (2007) Tissue factorpositive microparticles: cellular origin and association with coagulation activation in patients with colorectal cancer. Thromb Haemost 97(1):119-123

213. Auwerda JJ, Yuana Y, Osanto S, de Maat MP, Sonneveld P, Bertina RM, Leebeek FW (2010) Microparticle-associated tissue factor activity and venous thrombosis in multiple myeloma. Thromb Haemost 105 (1) (in press)

214. Tesselaar ME, Romijn FP, Van Der Linden IK, Prins FA, Bertina RM, Osanto S (2007) Microparticle-associated tissue factor activity: a link between cancer and thrombosis? J Thromb Haemost 5(3):520-527

215. Matsubara E, Shoji M, Murakami T, Abe K, Frangione B, Ghiso J (2002) Platelet microparticles as carriers of soluble Alzheimer's amyloid beta (sAbeta). Ann NY Acad Sci 977: 340-348

216. Koga H, Sugiyama S, Kugiyama K, Fukushima H, Watanabe K, Sakamoto T, Yoshimura M, Jinnouchi H, Ogawa H (2006) Elevated levels of remnant lipoproteins are associated with plasma platelet microparticles in patients with type-2 diabetes mellitus without obstructive coronary artery disease. Eur Heart $\mathbf{J}$ 27(7):817-823

217. Tan KT, Tayebjee MH, Lim HS, Lip GY (2005) Clinically apparent atherosclerotic disease in diabetes is associated with an increase in platelet microparticle levels. Diabet Med 22(12): 1657-1662

218. Diamant M, Nieuwland R, Pablo RF, Sturk A, Smit JW, Radder JK (2002) Elevated numbers of tissue-factor exposing microparticles correlate with components of the metabolic syndrome in uncomplicated type 2 diabetes mellitus. Circulation 106(19): $2442-2447$
219. Omoto S, Nomura S, Shouzu A, Nishikawa M, Fukuhara S, Iwasaka T (2002) Detection of monocyte-derived microparticles in patients with Type II diabetes mellitus. Diabetologia 45(4): $550-555$

220. Esposito K, Ciotola M, Giugliano D (2006) Pioglitazone reduces endothelial microparticles in the metabolic syndrome. Arterioscler Thromb Vasc Biol 26(8):1926

221. Agouni A, Lagrue-Lak-Hal AH, Ducluzeau PH, Mostefai HA, Draunet-Busson C, Leftheriotis G, Heymes C, Martinez MC, Andriantsitohaina R (2008) Endothelial dysfunction caused by circulating microparticles from patients with metabolic syndrome. Am J Pathol 173(4):1210-1219

222. Faure V, Dou L, Sabatier F, Cerini C, Sampol J, Berland Y, Brunet P, Dignat-George F (2006) Elevation of circulating endothelial microparticles in patients with chronic renal failure. J Thromb Haemost 4(3):566-573

223. Ayers L, Ferry B, Craig S, Nicoll D, Stradling JR, Kohler M (2009) Circulating cell-derived microparticles in patients with minimally symptomatic obstructive sleep apnoea. Eur Respir J 33(3):574-580

224. Yun CH, Jung KH, Chu K, Kim SH, Ji KH, Park HK, Kim HC, Lee ST, Lee SK, Roh JK (2010) Increased circulating endothelial microparticles and carotid atherosclerosis in obstructive sleep apnea. J Clin Neurol 6(2):89-98

225. Gonzalez-Quintero VH, Smarkusky LP, Jimenez JJ, Mauro LM, Jy W, Hortsman LL, O'Sullivan MJ, Ahn YS (2004) Elevated plasma endothelial microparticles: preeclampsia versus gestational hypertension. Am J Obstet Gynecol 191(4):1418-1424

226. Gonzalez-Quintero VH, Jimenez JJ, Jy W, Mauro LM, Hortman L, O'Sullivan MJ, Ahn Y (2003) Elevated plasma endothelial microparticles in preeclampsia. Am J Obstet Gynecol 189(2): 589-593

227. Knight M, Redman CW, Linton EA, Sargent IL (1998) Shedding of syncytiotrophoblast microvilli into the maternal circulation in pre-eclamptic pregnancies. Br J Obstet Gynaecol 105(6):632-640

228. Goswami D, Tannetta DS, Magee LA, Fuchisawa A, Redman CW, Sargent IL, von Dadelszen P (2006) Excess syncytiotrophoblast microparticle shedding is a feature of early-onset preeclampsia, but not normotensive intrauterine growth restriction. Placenta 27(1):56-61

229. VanWijk MJ, Nieuwland R, Boer K, van der Post JA, VanBavel E, Sturk A (2002) Microparticle subpopulations are increased in preeclampsia: possible involvement in vascular dysfunction? Am J Obstet Gynecol 187(2):450-456

230. Lok CA, Nieuwland R, Sturk A, Hau CM, Boer K, Vanbavel E, Vanderpost JA (2007) Microparticle-associated P-selectin reflects platelet activation in preeclampsia. Platelets 18(1):68-72

231. Soriano AO, Jy W, Chirinos JA, Valdivia MA, Velasquez HS, Jimenez JJ, Horstman LL, Kett DH, Schein RM, Ahn YS (2005) Levels of endothelial and platelet microparticles and their interactions with leukocytes negatively correlate with organ dysfunction and predict mortality in severe sepsis. Crit Care Med 33(11):2540-2546

232. Mostefai HA, Meziani F, Mastronardi ML, Agouni A, Heymes C, Sargentini C, Asfar P, Martinez MC, Andriantsitohaina R (2008) Circulating microparticles from patients with septic shock exert protective role in vascular function. Am J Respir Crit Care Med 178(11):1148-1155

233. Nieuwland R, Berckmans RJ, McGregor S, Boing AN, Romijn FP, Westendorp RG, Hack CE, Sturk A (2000) Cellular origin and procoagulant properties of microparticles in meningococcal sepsis. Blood 95(3):930-935 